
UNITED STATES DEPARTMENT OF THE INTERIOR

J. A. Krug, Secretary

GEOLOGICAL SURVEY

W. E. Wrather, Director

\section{Bulletin 954-E}

\section{MANGANESE DEPOSITS OF THE}

\section{TALAMANTES DISTRICT NEAR \\ PARRAL, CHIHUAHUA, MEXICO}

BY

I. F. WILSON AND V. S. ROCHA

Prepared in cooperation with the DIRECCION GENERAL DE MINAS Y PETROLEO, SECRETARIA DE LA ECONOMIA NACIONAL DE MEXICO under the auspices of the INTERDEPARTMENTAL COMMITTEE ON SCIENTIFIC AND CULTURAL COOPERATION, DEPARTMENT OF STATE

Geologic Investigations in American Republics, 1946 (Pages 181-208)

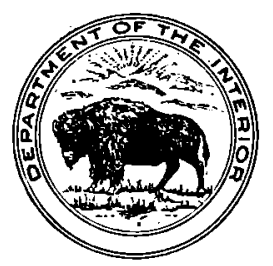

UNITED STATES

GOVERNMENT PRINTING OFFICE

WASIIINGTON : 1948

For sale by the Superintendent of Documents, U. S. Government Printing Office, Washington 25, D. C. Price 50 cents 



\section{CONTENTS}

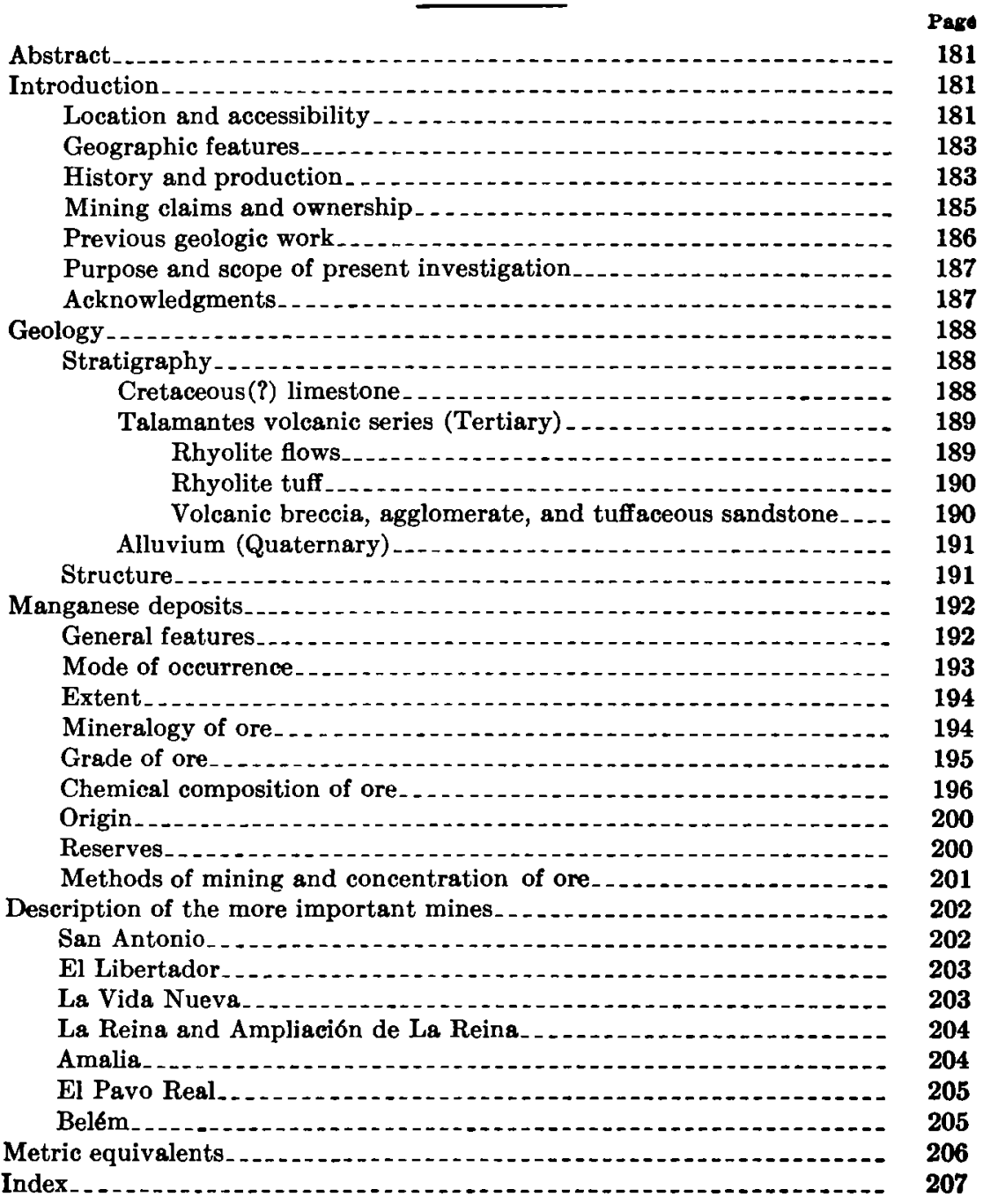




\section{ILLUSTRATIONS}

Page

Plate 33. Cliffs of rhyolite .............. 184

34. Geologic map and structure section of the Talamantes manganese district, State of Chihuahua, Mexico ............ In pocket

35. $A$, Hill east of the Mesa de Talamantes; $B$, East side of the Mesa de Talamantes, showing fault-line scarp formed by La Concepción fault

36. $A$, Specimen of typical ore from San Antonio mine; $B$, Specimen of ore from San Antonio mine

37. $A$, Specimen of psilomelane from San Antonio mine; $B$, Hand jigs used to concentrate manganese ore at the San Antonio

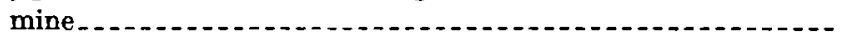

38. Map and longitudinal sections of the San Antonio manganese mine......... In pocket

Figure 16. Index map of Mexico showing location of the Talamantes

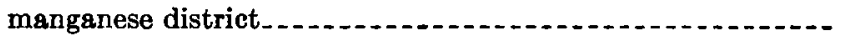




\title{
MANGANESE DEPOSITS OF THE TALAMANTES DISTRICT NEAR PARRAL, CHIHUAHUA, MEXICO
}

\author{
By I. F. WIIson and V. S. RocHA
}

\begin{abstract}
The Talamantes district, 20 kilometers east of Parral in southern Chihuahua, has been the second largest producer of manganese ore in Mexico. Production, which started during World War I and has been more or less continuous since 1930 , has totaled about 50,000 tons of ore with an average manganese content of 40 or 41 percent. The mines are on the Mesa de Talamantes, which is underlain by folded Cretaceous (?) limestone, overlain unconformably by gently dipping Tertiary rhyolite flows and tuff, volcanic breccia, agglomerate, and tuffaceous sandstone. Steeply dipping normal faults of northerly trend cut the rock and divide the mesa into a series of blocks.

The manganese deposits occur in brecciated zones along the faults, chiefly in the rhyolite. Several vein systems as much as several hundred meters long occur in the district. The thickness of the ore zones ranges from 1 to 2 meters up to 8 meters. The greatest depth of exploration is 42 meters. The manganese minerals are psilomelane, cryptomelane, hollandite-cryptomelane, coronadite, and an unnamed manganese oxide mineral. The associated minerals are calcite, chalcedony, barite, quartz (including amethyst), gypsum, and hematite. From one half to $1 \frac{1}{2}$ percent of $W_{B}$ occurs in the ore, contained within the mineral psilomelane. The tungsten does not appear to be economically exploitable. Thick barite veins occur in the district. The manganese ore was deposited along brecciated fault zones by manganiferous solutions containing barium and tungsten; certain features suggest ascending hydrothermal solutions, though conclusive evidence to this effect was not found.

Half the ore, in general, is composed of rhyolite fragments. The grade of the ore in place, 20 to 30 percent manganese, can be increased by hand picking and hand jigging to 40 or 44 percent manganese. The sorting results in considerable loss. Reserves of about 100,000 to 125,000 tons of ore containing 20 to 30 percent of manganese are inferred; sorting would produce approximately half this tonnage of ore containing 40 to 44 percent of manganese. In addition, about 25,000 tons of dump ore contains 10 to 30 percent of manganese.
\end{abstract}

\section{INTRODUCTION}

\section{LOCATION AND ACCESSIBILITY}

The Talamantes manganese district is 20 kilometers east of Parral (officially called Hidalgo del Parral), in the Municipio ${ }^{1}$ de Allende, southern Chihuahua. (See fig. 16.) The district lies near the western edge of the high central plateau of Mexico. Parral, a town of 24,000 inhabitants, is one of the famous silver-lead-zinc camps of Mexico

1 Approximately equivalent to "county" In the United States. 


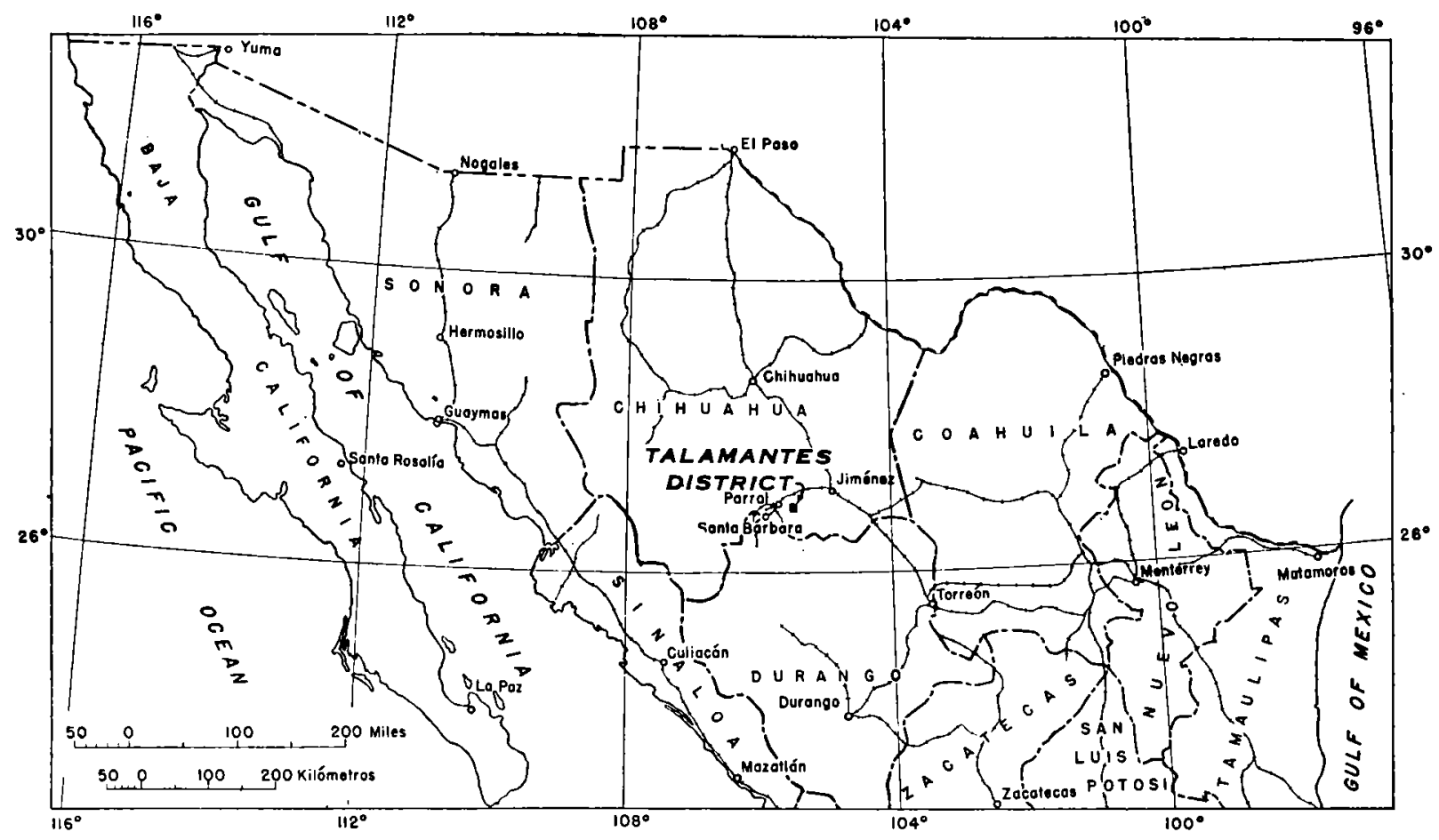


and has a mining history dating back to the year $1632 .{ }^{2}$ Talamantes, $21 / 2$ kilometers east of the manganese district, is a small village of a few hundred inhabitants. Parral is on the Jiménez-Santa Bárbara branch line of the Ferrocarriles Nacionales de México. The railroad station nearest the manganese district is Morita, 17 kilometers to the north by a road poorer than that running to Parral. Both the road to Morita and that to Parral have been used for shipping ore. The road from Talamantes to Parral is in fair condition and is passable during all but the rainiest period of the year, which is during the summer months.

\section{GEOGRAPHIC FEATURES}

The manganese deposits are within and along the borders of the Mesa de Talamantes, which consists of rocky hills of boldly outcropping rhyolite rising 100 to 150 meters above the general level of the surrounding plains. The mesa has an altitude of 1,850 to 1,950 meters and is bordered on the west and east by cliffs 25 to 40 meters high. It is about $41 / 2$ kilometers long in a northerly direction and 1,200 to 1,400 meters wide. To the south the mesa terminates in alluvium-blanketed plains, which extend for several kilometers; to the north it merges into rolling hills. To the west and east there are plains from which rise other smaller hills of rhyolite.

Near the north end of the manganese district the mesa is crossed by the Río de Valle Allende (also called the Río de Santa Bárbara by local inhabitants), which has cut a deep narrow gorge through the rhyolite with cliff's as much as 50 meters high. (See pl. 33.) A small dam has been constructed west of the mesa, and the flow of the stream is controlled so that a supply of water is available the year round. The amount of water would be sufficient for the operation of a small mill. Water for operating hand jigs is carried from the river by truck to the San Antonio mine and by burros to the smaller mines in the district. Except for a few trees growing along the river, the only vegetation in the region consists of grass and low shrubs.

\section{HISTORY AND PRODUCTION}

The Talamantes manganese district has had the second largest production record of any manganese district in Mexico, being exceeded only by the Lucifer mine in Baja California. The deposits were worked on a small scale during World War I. Production was intermittent during the succeeding years until 1930; since then production has been more or less continuous from the mines of the Fernández brothers and from the properties of César Díaz. Until World War II most of the production went to the steel plant at Monterrey, Nuevo

\footnotetext{
2 Dominguez, Norberto, The district of Hidalgo del Parral, Mexico, in 1820: Am. Inst. Min. Eng. Trans., vol. 32, p. 461, 1902.
} 
León, operated by Cía. Fundidora de Fierro y Acero de Monterrey, S. A. During World War II ore was shipped also to the Metals Reserve Co. at El Paso, Tex. The production rate at the San Antonio mine early in 1944 was said by the operators to be about 350 tons of ore a month. About 30 men were employed by the Fernández brothers at the San Antonio mine in April 1944. The other properties were being worked only by "gambusinos," " who altogether may total between 50 and 80 men at different times. Many of these gambusinos are engaged in working over old dumps.

Production figures are approximate as they are based largely upon conversations with the operators. There are very few published figures, and there are no records for many of the rnines in the district. The only published figures are those given in the Anuario de Estadística Minera for the years 1923, 1925, and 1926, as follows:

Published figures on production of manganese ore from Talamantes district

\begin{tabular}{c|r|r}
\hline Year & $\begin{array}{r}\text { Fernández } \\
\text { properties } \\
\text { (metric tons) }\end{array}$ & $\begin{array}{r}\text { Libertador mine } \\
\text { (metric tons) }\end{array}$ \\
\hline 1923 & 100 & 140 \\
1925 & 90 & \\
\hline
\end{tabular}

No further production figures are given in later issues of the Anuario, which extend through 1933, although it is known that there was considerable production from the district starting at least as early as 1930. Since 1933 the figures on manganese production published in Mexico have given only the total for the country by years and not the production from individual mines.

According to the Fernández brothers the total production from their properties through April 1944 was about 36,000 tons of ore. They list the production by individual properties as follows:

Production of manganese ore from mines of the Fernandez brothers through April 1944

San Antonio

Metrio tons

La Reina 21,800

Amalia 2 and Ampliación de Amalia 2 4,600

Ampliación de La Reina. 3,900

La Protección 2,300

El Pavo Real 1,600

Estela 1,000 900

" "Gambusinos" are miners who work independently and are pald a set price for the ore they produce.

4 Mexico, Departamento de minas: Anuarlo de Estadistica Minera, 1923, p. 85, 1925; 1925 , p. 169,$1927 ; 1926$, p. $266,1928$. 


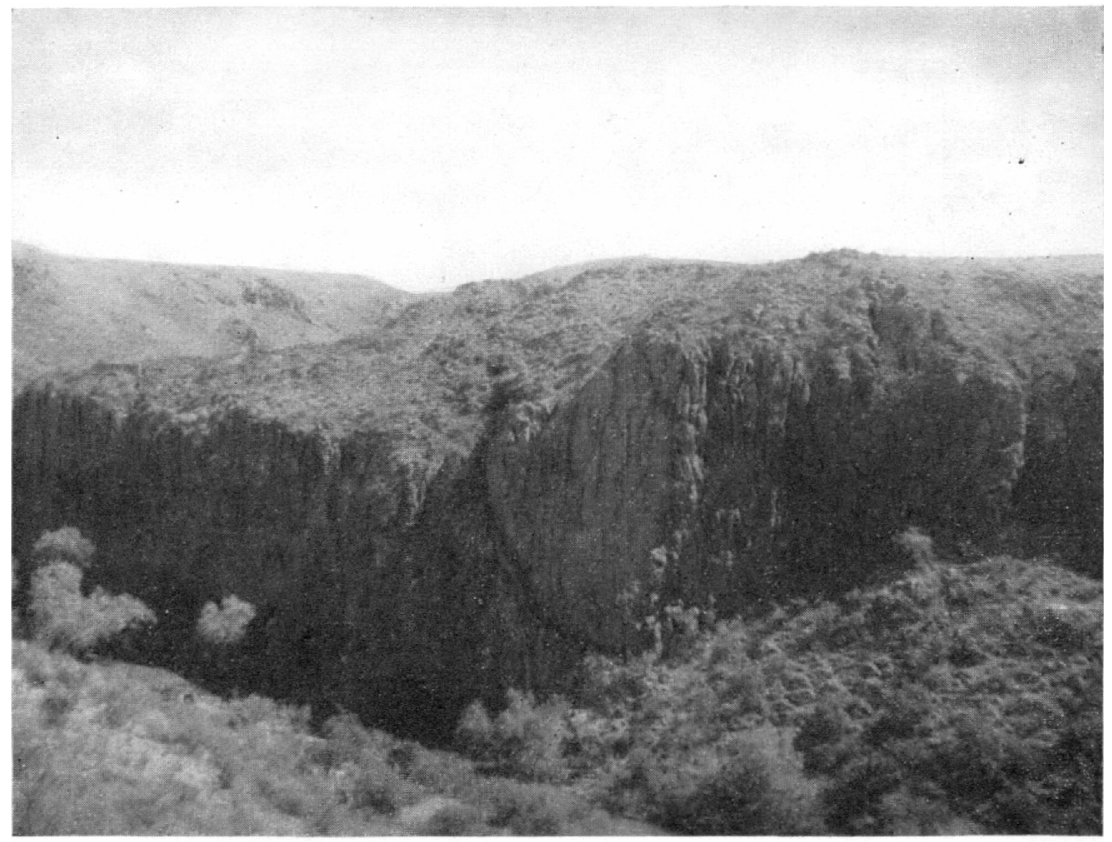

CLIFFS OF RHYOLITE.

Lowking south across the Rin de Valle Allende on the Amalia claim. Dark -lreak almug the cliff in cenler of picture is a fissure in the rhyolite. 

The production from other properties in the district is not known but is thought to be of the magnitude of 15,000 tons, mostly from the El Libertador and La Vida Nueva mines. The total production of the district thus may be about 50,000 tons of ore, but this figure is very tentative. The manganese content of the ore shipped from the properties of the Fernández brothers is said to have ranged from 40 to 44 percent. Some of the ore shipped from the district may have contained less than 40 percent of manganese, but the average manganese content has probably been close to 40 or 41 percent.

\section{MINING CLAIMS AND OWNERSHIP}

The manganese district is covered by 27 claims, owned by 4 groups of persons. Names and boundaries of the claims are given on the topographic and geologic map (pl. 34). Most of the claims in the southern part of the district, including the largest active producer, the San Antonio, are owned by the brothers J. Antonio Fernández and Horacio Fernández of Parral. The claims in the northern part of the district are controlled by César Díaz. Five claims are owned by Saturnino Chávez and one by Francisco Aguirre. A list of the names of the claims, the numbers of the titles, and the owners follows. This information was obtained from conversations with local inhabitants and is not an official list; in a few instances discrepancies were noted in the information obtained from various sources. The claims are listed geographically from north to south.

Mining claims in the Talamantes district

\begin{tabular}{|c|c|c|}
\hline Name & Title number & Owner \\
\hline El Centinela_ & Tit. 102814 & César Díaz. \\
\hline La Libertad & Exp. 689 & Do. \\
\hline El Libertador. & Tit. 24441 & Do. \\
\hline El Libertador No. 2 & Tit. 32661 & Do. \\
\hline El Libertador $\mathrm{N}$ & Tit. 32662 & Do. \\
\hline Las Coloradas. & Tit. 100625 & Do. \\
\hline Barón de Humboldt & Tit. 100348 & Do. \\
\hline Santo Domingo. & Tit. 98034 & Saturnino Chá vez. \\
\hline Olivia_. & Tit. 107998 & Fernández brothers. \\
\hline Amalia No. 2 & Tit. $57270_{-}$ & $\begin{array}{l}\text { Francisco Aguirre. For- } \\
\text { merly owned by Fernán- } \\
\text { dez brothers. }\end{array}$ \\
\hline Ampliación de Amalia No. 2.. & Tit. 58018 & Saturnino Chávez(?). \\
\hline $\begin{array}{l}\text { La Vida Nueva } \\
\text { La Vida Nueva No. } 2\end{array}$ & Tit. 93654 & César Díaz. \\
\hline $\begin{array}{l}\text { La Vida Nueva No. } 2 \\
\text { La Concepción }\end{array}$ & Exp. 725 & Disputed. \\
\hline $\begin{array}{l}\text { La Concepción. } \\
\text { La Esperanza..... }\end{array}$ & Tit. 82489 & Saturnino Chávez. \\
\hline $\begin{array}{l}\text { La esperanza } \\
\text { Susanita }\end{array}$ & $\begin{array}{l}\text { Mit. } 14084 \overline{-}^{-} \\
\text {Tit. } 101369\end{array}$ & Do. \\
\hline La Protección. & Tit. $10^{r}$ & Fernández brothers. \\
\hline La Victoria_. & Tit. 16. & Do. \\
\hline Estela & Tit. $94 \mathrm{~b} \angle \mathrm{a}$ & Do. \\
\hline San Antonio . - & Tit. $73997-$ & Do. \\
\hline La India & Tit. 73434 & César Díaz. \\
\hline
\end{tabular}


Mining claims in the Talamantes district-Continued

\begin{tabular}{|c|c|c|}
\hline Name & Title number & Owner \\
\hline $\begin{array}{l}\text { La Reina } \\
\text { Ampliación de La Reina. } \\
\text { El Occidente. } \\
\text { Guadalupe. } \\
\text { El Pavo Real } \\
\text { Belém }{ }^{1}\end{array}$ & $\begin{array}{l}\text { Tit. } 71541 \\
\text { Tit. } 72227 \\
\text { Tit. } 10147 \overline{2} \\
\text { Tit. } 12417 \\
\text { Tit. } 106972 . \\
\text { Title abandoned(?) }\end{array}$ & $\begin{array}{l}\text { Fernández brothers. } \\
\text { Do. } \\
\text { Do. } \\
\text { Do. } \\
\text { Do. }\end{array}$ \\
\hline
\end{tabular}

1 Boundaries of Belsm claim not shown on map, but location of veins and workings is indicated (extreme southeast corner of pl. 34).

\section{PREVIOUS GEOLOGIC WORK}

So far as known no previous geologic description of the Talamantes district has been published. The well-known Parral silver-lead-zinc district, 20 kilometers to the west, however, has received considerable attention. Papers reporting results of original geologic work on the Parral district include those by Waitz, ${ }^{5}$ Scalia ${ }^{6}{ }^{6}$ and Schmitt. ${ }^{7}$ Other papers, which give a relatively brief summary of the geology, include that by Weed, ${ }^{8}$ which covers mainly the area west of Parral, and those by Burr and Cates, ${ }^{9}$ Garrison, ${ }^{10}$ Bagg, ${ }^{11}$ Rice, ${ }^{12}$ Smith, ${ }^{13}$ Paredes, ${ }^{14}$ Campa, ${ }^{15}$ and Castanedo. ${ }^{18}$ Several other papers which deal with the mines at Parral but have little or no reference to the geology are not listed here. The geology of the area between Valle de Allende, 10 kilometers east of the Talamantes district, and Jiménez, which lies 60 kilometers to the east, has been described by Ordóñez. ${ }^{17}$

\footnotetext{
5 Waitz, Paul, Esquisse geologique et petrographique des environs de Hidalgo del Parral : Internat. Geol. Cong., X, Mexico, Guide Exc. No. 21, 21 pp., 1906.

- Scalia, Salvador, Geología de los alrededores de Hidalgo del Parral, Chihuahua : Bol. minero, vol. 4, pp. 230-233, 1917.

' Schmitt, H. A., Geology of the Parral area of the Parral district, Chihuahua, Mexlco: Am. Inst. Min. Met. Eng. Trans. 1931, pp. 268-290, 1931.

${ }^{8}$ Weed, W. H., Notes on a section across the Sierra Madre Occidental of Chihuahua and Sinaloa, Mexico : Am. Inst. Min. Eng. Trans., vol. 32, pp. 444-458, 1902.

- Burr, G. A., and Cates, L. S., The mining district of Parral, State of Chihuahua, Mertco : Eng. and Min. Jour., vol. 75, pp. 216-217, 1903.

${ }^{10}$ Garrison, F. L., The Parral district, Mexico: Min. and Sel. Press, vol. 94, pp. 373-374, 1907.

${ }^{11}$ Bagg, R. M. Jr., Geology of the mining districts of Chihuahua, Mexico : Min. and Scl. Press, vol. 97, pp. 152-153, 187-189, 1908.

12 Rice, C. T., The silicious silver mines of Parral, Mexico : Eng. and Min. Jour., vol. 86, pp. 276-280, 1908.

${ }^{18}$ Smith, F. W., Conditions at the Palmilla mine, Parral, Mexico : Eng. and Min. Jour., vol. 90, pp. 259-262, 1910.

14 Paredes, Trinidad, Apuntes sobre algunos minerales del estado de Chihuahua : Soc. geol. mexicana Bol. 8, p. 40, 1912.

${ }^{15}$ Campa, José, El distrito de Hidalgo, estado de Chihuahua: Bol. minero, vol. 19, pp. 178-200, 1925.

16 Castanedo, José, Los distritos mineros de Hidalgo del Parral, Santa Bárbara y Villa Escobedo, del estado de Chihuahua : Bol. minero, vol. 24, pp. 90-98, 1927.

${ }^{17}$ Ordoñez, Ezequiel, Itinerarios geológicos, in Bosquejo geologico de México: Inst. geol. México Bol. 4, 5, 6, pp. 75-77, 1896.
} 


\section{PURPOSE AND SCOPE OF PRESENT INVESTIGATION}

The Talamantes district was first examined on behalf of the Geological Survey by Parker D. Trask in 1943, during a general survey of the manganese resources of Mexico. It was one of the manganese districts in Mexico chosen for further geologic study and mapping. Assigned to the project were Kenneth Segerstrom, topographer, and Ivan F. Wilson, geologist, representing the Geological Survey, and Ing. Victor S. Rocha M., representing the Dirección General de Minas y Petróleo. In March 1944 Segerstrom made a topographic map of the Mesa de Talamantes on a scale of 1:5,000, with a contour interval of 5 meters, covering an area about $4 \frac{1}{2}$ kilometers long and 2 kilometers wide and including all the known manganese deposits in the district. From April 13 to May 3, 1944, Wilson and Rocha mapped the geology, made mine maps and sections of the principal underground workings on a scale of $1: 1,000$, and investigated the manganese deposits.

The present study is a cooperative project of the Geological Survey, United States Department of the Interior, and the Dirección General de Minas y Petróleo, Secretaría de la Economía Nacional de México. This is part of a series of geologic investigations in the American Republics sponsored by the Interdepartmental Committee on Scientific and Cultural Cooperation under the auspices of the United States Department of State.

\section{ACKNOWLEDGMENTS}

Acknowledgments are due Sres. J. Antonio Fernández and Horacio Fernández for their hospitality during the course of the field work. Many courtesies and much helpful assistance were given by officials of the American Smelting and Refining Co. in Parral, particularly by J. H. Hannan, Chief Engineer. In this as well as in the other geologic investigations in Mexico cordial cooperation was extended by the Instituto de Geología and its Director, Sr. Ing. Teodoro Flores, as well as the Dirección General de Minas y Petróleo and its Director, Sr. Ing. Germán García Lozano. Parker D. Trask gave helpful suggestions for the investigation, and a number of analyses in this report are of samples collected by him. Other samples were collected by Charles E. Pouliot of the Foreign Economic Administration. Results of mill tests were supplied by T. E. Dickel and W. J. Shedwick of the Foreign Economic Administration. Several members of the Geological Survey contributed to the study: Robert L. Smith examined a number of thin sections; Michael Fleischer supplied chemical analyses; and J. M. Axelrod made X-ray determinations of the ore minerals. The work was under the general supervision of D. F. Hewett, J. V. N. Dorr 2d, and W. F. Foshag. 


\section{GEOLOGY}

The Mesa de Talamantes is composed of rhyolite flows, rhyolite tuff, volcanic breccia, agglomerate, and tuffaceous sandstone, all gently dipping. All are of Tertiary age and are herein called the Talamantes volcanic series. These volcanic rocks rest unconformably upon folded limestones, which are probably of Cretaceous age. The rocks are cut by normal faults having a general northerly trend. Veins of manganese oxide follow brecciated zones along the faults.

\section{STRATIGRAPHY}

\section{CRETACEOUS (?) LIMESTONE}

The oldest rock exposed in the district is folded limestone, which occurs within the area mapped in the plains east of the Mesa de Talamantes. The limestone is thin-bedded to moderately thick-bedded, the individual beds ranging from 1 to 30 centimeters in thickness. A few thin shaly layers are interbedded with the limestone. The general color of the limestone is gray or yellow, and in places reddish stains are present. The limestone is less resistant to erosion and produces a more gentle topography and lighter-colored soil than the overlying rhyolite. (See pl. 35 A.)

The attitude of the limestone beds is variable within short distances. In most of the area studied the beds are tilted at high angles and are strongly wrinkled and contorted. The contact between the limestone and overlying rhyolite is marked by a pronounced angular unconformity. The rhyolite flowed over an uneven surface which had a relief of several meters.

No fossils were found in the limestone, and within the small area studied no definite evidence was found regarding its age, but from the known geologic history of this part of Mexico there is little doubt that it is pre-Tertiary and most likely Cretaceous. Fossils found in similar limestones and shales in the Parral district, 20 kilometers west. of Talamantes, were classed by Burckhardt ${ }^{18}$ as middle Cretaceous (Gault-Vraconnien stage). In the classification of Imlay ${ }^{10}$ the rocks containing these fossils are tentatively placed from the upper Albian to the lower Cenomanian. In 1907 dinosaur tracks were found near Parral in the same group of rocks, according to Freudenberg. ${ }^{20} \mathrm{Waitz}{ }^{21}$ and Burckhardt ${ }^{22}$ state that the same series of rocks extends as far east as Jiménez, which is 60 kilometers east of Talamantes; the area

\footnotetext{
19 Burckhardt, C. E., Etude synthétique sur le Mesozoique Mexicain, seconde partie : Soc. paléont. Suisse Mém., vol. 50, p. 174, 1931.

10 Imlay, R. W., Cretaceous formations of Central America and Mexico: Am. Assoc. Petroleum Geologists Bull., vol. 28, pp. 1086, 1169, 1944.

${ }^{20}$ Freudenberg, Wilhelm, Geologie von Mexico: dargestellt nach der Literatur und nach eigenen Forschungen, p. 122, Berlín, Gebrüđer Borntraeger, 1921.

$n$ Waitz, Paul, op. cit., p. 4.

${ }^{22}$ Burckhardt, C. E., op. cit., p. 174.
} 
thus covered would include the Talamantes district. Although in the present study the limestones of the Talamantes district were not traced into those of the Parral district, it seems possible that they are of the same age, that is, middle Cretaceous.

\section{TALAMANTES VOLCANIC SERIES (TERTIARY)}

The Talamantes volcanic series consists of rhyolite flows, rhyolite tuff, volcanic breccia, agglomerate, and tuffaceous sandstone. The series has a thickness of at least 155 meters on the Mesa de Talamantes. The breccia, agglomerate, and sandstone are intercalated near the top of the series. They overlie the bulk of the rhyolite flows, but in at least one locality thinner rhyolite flows overlie the volcanic breccia.

The volcanic breccia, agglomerate, and sandstone have a minimum thickness of 35 meters. The rhyolite flows and intercalated tuff are at least 120 meters thick on the Mesa de Talamantes. Their complete thickness cannot be measured, because the base of the flows is exposed only east of the La Concepción fault, whereas the top of the flows is exposed only west of the fault, and the amount of displacement along the fault is unknown.

The Talamantes volcanic series is part of the widespread group of rhyolitic volcanic rocks found in the western part of the high central plateau and in the Sierra Madre Occidental of Mexico, extending from near the United States border as far south as the State of Guerrero, south of Mexico City. The distribution and geologic features of the extensive Tertiary rhyolites of Mexico are described in a monograph by Ordónez,$^{23}$ who concluded that the age is Pliocene. King ${ }^{24}$ has described extensive volcanic rocks, mainly andesites and rhyolites, in the Sierra Madre Occidental of southeastern Sonora and western Chihuahua, which he considered of "early Tertiary" age. Their exact position within the Tertiary evidently is not well defined, however, for the only limiting formations listed by him are Cretaceous below and the Bácarit formation above, which contains fossils suggesting a "late Tertiary or a Quaternary age." ${ }_{25}$ Within the Talamantes district no specific evidence was found bearing on the age of the rhyolitic volcanic rocks, but there is little doubt that they are Tertiary.

Rhyolite flows.-The major portion of the Mesa de Talamantes is made up of massive resistant rhyolite, which unconformably overlies the limestone. In general the color is gray, although in some places the rock is stained reddish; in many places black stains of manganese oxide are present. The rock is porphyritic and has an aphanitic groundmass. In places it is vesicular, the vesicles being strung out in

${ }^{28}$ Ordoñez, Ezequiel, Las riolitas de Mexico : Inst. geol. México Bol. 14, 75 pp., 1900 ; Bol. 15, $76 \mathrm{pp}$., 1901. Includes a map of Mexico showing distribution of the rhyolites.

24 King, R. E., Geological reconnaissance in northern Sierra Madre Occidental of Mexico: Geol. Soc. America Bull., vol, 50, pp. 1678-1681, 1939.

${ }^{25} \mathrm{King}$, R. E., op. cit., p. 1692. 
bands. A thin-section study by Robert L. Smith reveals sanidine phenocrysts in a groundmass of quartz, orthoclase, devitrified glass, and some magnetite. Flow structure is indicated by elongate wisps of devitrified glass. In some specimens examined in the field, phenocrysts of biotite and hornblende were identified under a hand lens.

Inasmuch as most of the rhyolite is massive, the attitude is difficult to determine, except where vesicular bands or intercalations of tuff are present. In all places where it was observed the dip was fairly gentle, ranging from $5^{\circ}$ to $30^{\circ}$ either to the west or east.

All the important manganese deposits in the district occur in brecciated zones and fissures in the rhyolite.

Rhyolite tuff.-Intercalated with the rhyolite flows, in places, are layers of firmly compacted gray tuff, similar in general appearance to the rhyolite except that it has a granular texture. The rock appears to be a welded tuff. A thin section studied by Smith contains phenocrysts of quartz and inclusions of tuff, pumice, and rhyolitic rock fragments in a groundmass of devitrified glass shards and a very fine microcrystalline aggregate of quartz and orthoclase, which is probably also a product of devitrification of glass.

Volcanic breccia, agglomerate, and tuffaceous sandstone.-Reddish volcanic breccia, agglomerate, and tuffaceous sandstone are intercalated near the top of the Talamantes volcanic series on the Mesa de Talamantes. In general the volcanic breccia occurs entirely above the rhyolite, but in at least one place a thin flow of rhyolite overlies the breccia. All contacts between the rhyolite and breccia appear to be conformable. The volcanic breccia consists of angular fragments of rhyolite and of devitrified rhyolitic tuffs contained in a reddish, sandy matrix cemented by iron oxide and fine-grained tuffaceous materials. In places the rhyolite fragments are so tightly packed together that very little of the red sandy matrix is present, but more commonly the fragments are widely scattered through the reddish matrix.

The breccia grades into reddish tuffaceous sandstone of the same nature as the sandy matrix but lacking the larger rhyolite fragments. Smith describes a thin section of this rock as follows:

This rock is composed of detrital orthoclase, quartz, and devitrified tuff fragments which are cemented by iron oxide and bentonitic material. Orthoclase comprises about 70 percent of the larger mineral grains, quartz about 20 percent, whereas the remaining grains are rounded tuff fragments and grains of a greenish clay mineral which is probably nontronite. These clay grains appear to have formed in place by the alteration of some ferromagnesian mineral. Most of the grains show some degree of rounding, but some are still quite angular.

The orthoclase, which is of the variety sanidine, and the quartz grains look like phenoerysts of porphyritic volcanics and were no doubt derived from the underlying rhyolites. Beds of tuffaceous sandstone of 
this type several meters thick occur at intervals within the breccia and agglomerate. Widely spaced bedding planes are fairly well defined.

The volcanic breccia and accompanying rocks are exposed mainly in two belts, one on each side of the Mesa de Talamantes near its south end. Both belts are truncated by faults. A smaller patch occurs in the center of the mesa, southeast of the San Antonio mine, and another belt occurs west of the mesa, on both sides of the Río de Valle Allende. In places the breccia is inclined at angles of $25^{\circ}$ to $30^{\circ}$.

A few small manganese deposits occur in the volcanic breccia, particularly on the El Pavo Real claim, but the larger mines of the district are confined to the rhyolite flows.

\section{ALLUVIUM (QUATERNARY)}

Alluvial fans flank the sides of the Mesa de Talamantes, and alluvium is encountered in the arroyos. The plains to the south of the mesa are blanketed by thick alluvial deposits. A shaft just south of the Belém claim penetrated 10 meters of alluvium without striking bedrock.

\section{STRUCTURE}

The Cretaceous(?) limestone was highly folded before the Talamantes volcanic series was formed. The attitude of the limestone is so variable that no general structural trend is apparent within the relatively small area studied.

The Talamantes volcanic series has been gently tilted and cut by a series of normal faults. The displacement along the faults is not always evident, but wherever it could be determined by stratigraphic evidence the movement was normal. The faults have a general northerly trend. The average strike is $\mathrm{N} .5^{\circ}-10^{\circ} \mathrm{W}$., but the strike ranges to slightly east of north. The dip of the faults ranges from vertical to $60^{\circ}$ to the west or east. Most of the faults are followed by brecciated zones ranging in thickness from a fraction of a meter to 3 or 4 meters. In most places the faults have smooth slickensided footwalls; in a few places the hanging wall is more distinct: Striations and grooves may be observed along the faults in places; most commonly, they have a pitch more nearly horizontal than vertical, which indicates a large horizontal component.

In the latitude of the San Antonio mine the Mesa de Talamantes is traversed by four main northward-trending fault zones, which divide the mesa into a series of blocks. Proceeding from west to east, the mesa consists of: (1) a horst, bordered on the west by the $\mathrm{La}$ Reina fault and on the east by the San Antonio fault; (2) a minor graben, between the San Antonio and Belém faults; and (3) an eastward-tilted block, bordered on the west by the Belém fault and on the east by a fault-line scarp of the La Concepción fault. 
The La Reina fault, which borders the mesa on the west, is followed along much of its length by a fault scarp 25 to 30 meters high. The fault surface cannot be seen along the entire length, as it is obscured for the most part by alluvium, but it can be observed in the La Reina mine, where there is a brecciated zone along it as much as 8 meters wide. At this point the fault strikes N. $10^{\circ} \mathrm{W}$. and dips $80^{\circ} \mathrm{W}$. Farther north there is stratigraphic evidence for the faulting, in that the volcanic breccia overlying the rhyolite has been dropped down on the west side of the mesa.

The center of the Mesa de Talamantes, between the San Antonio and El Pavo Real mines, consists of a small graben, bordered by the San Antonio fault on the west and the Belém fault on the east. In part, the overlying volcanic breccia is dropped down into this graben. The San Antonio fault curves southwest and intersects the La Reina fault on the El Pavo Real claim. The San Antonio fault cannot be traced continuously on the surface as far north as the San Antonio mine, but the San Antonio vein system is believed to be along a continuation of the same fault system. The Belém fault is followed by barite veins which contain a little manganese oxide.

The La Concepción fault on the east side of the mesa differs from the others in that it forms a fault-line scarp rather than a fault scarp. The stratigraphic evidence seems clear that the east side of the fault has been thrown up, but the topographic scarp appears on the west side. The fault dips west, so it is normal like the others. Manganese oxide occurs in brecciated zones along the fault at several scattered localities. The underlying limestone on the east side of the fault is brought into contact with rhyolite and in part with the overlying volcanic breccia, which have been dropped down on the west side. (See pl. 35 B.) The conformable contact between rhyolite and volcanic breccia runs into the fault in two places. The fault cannot be traced across the alluvium of the Río de Valle Allende to the north, but there are two possible lines of continuation-the El Libertador vein system, directly north, or another fault having a similar dip and displacement which-occurs a short distance east of the Libertador vein.

Many other smaller faults occur in the district; in fact nearly all the many veins indicated on the map (pl. 34) follow fault zones. In many places the faults branch along their strike, and a few of the small branches trend more nearly eastward than northward.

\section{MANGANESE DEPOSITS}

\section{GENERAL FEATURES}

The manganese deposits of the Talamantes district consist of manganese oxides in brecciated zones along faults. About half the ore as it occurs in place consists of fragments of rhyolite. The San 


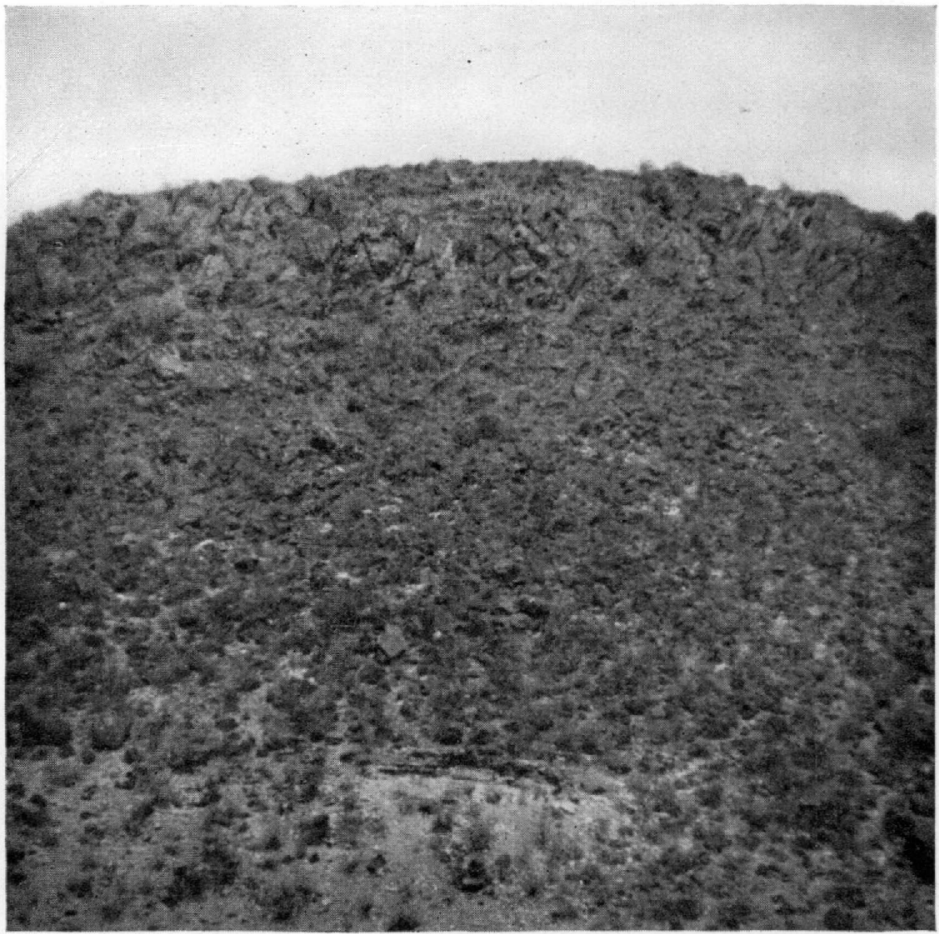

A. HILL EAST OF THE YESA DF TALAMANTES.

Lawking east. Shows irregular rontar! hetween dark-colured thyolite tubuses and lightecoluted limestone. (below).

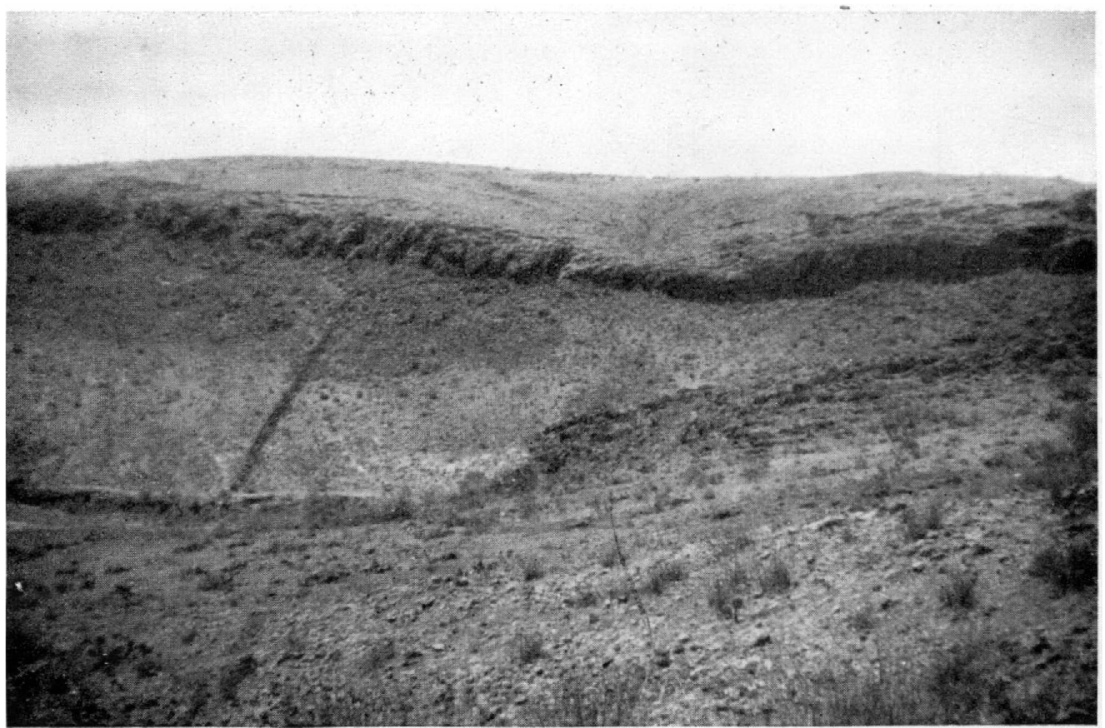

P. FAST SIDE UF THE MESA DE TALANATTES.

Louking west. Shows fault line scarp formed by La Concepción fault. Clifts are composed of rhyolite; bediled rocks above are yolcanic breccia, agglomerate, and tufaceous sandstone. Light-colored soil in ratine in fore. ground formed from limestone. 

Antonio vein system has been explored for a length of 550 meters at a depth of 23 meters; it has an average width of 2 meters. Several other vein systems have lengths of hundreds of meters. The deposits have not been explored to any great depth. The manganese minerals include psilomelane, cryptomelane, hollandite-cryptomelane, coronadite, and an unnamed manganese mineral. The manganese oxides are accompanied by calcite, chalcedony, quartz, gypsum, iron oxides, and barite. Thick barite veins containing minor amounts of manganese oxide occur in the district. The average grade of ore in place is 20 to 30 percent of manganese, but by sorting and jigging the grade of the shipping product is raised to 40 or 44 percent of manganese. The ore contains one-half to $1 \frac{1 / 2}{2}$ percent of $\mathrm{WO}_{3}$. The tungsten is contained in the mineral psilomelane. The barium content of the ore averages about 8 percent $\mathrm{BaO}$. The run-of-mine ore contains as much as 35 percent of silica, but the shipping product from which most of the rhyolite fragments have been sorted out contains about 9 percent of silica. Lead is absent from the San Antonio mine ore, but several percent occurs in part of the district in the mineral coronadite.

\section{MODE OF OCCURRENCE}

Most of the manganese deposits of the Talamantes district occur in brecciated zones along faults. Manganese oxides occur as veinlets, irregular nodular bodies, and irregular masses surrounding rhyolite fragments of the breccia. About half the volume of the breccia zones is composed of fragments of wall rock. (See pl. $36 \mathrm{~A}$.) The manganese oxides have filled open spaces and probably replaced the matrix of the breccia, but the rhyolite fragments show very little evidence of replacement. In many places narrow stringers of manganese oxide extend from the brecciated zones into the bordering wall rock. In some places fairly well defined veins of manganese oxide having definite walls occur along fissures not accompanied by breccia zones. These veins are much thinner, however, than the breccia deposits. Most of these individual well-defined veins are only a few centimeters thick, very few of them being as much as half a meter, whereas many of the breccia deposits are 2 meters or more thick.

The faults along which the veins occur have dips ranging from vertical to $60^{\circ} \mathrm{E}$. or $\mathrm{W}$. The average strike is a few degrees west of north, but the strike ranges to slightly east of north. In many places smaller cross fractures branch off at an angle from the main faults and are filled with stringers of manganese oxide. Most of the faults have smooth distinct footwalls with slickensided surfaces; in a few places the hanging wall is smooth. However, in any particular local. ity, generally only one wall is definite, and the other boundary of the brecciated zone is gradational. 
In places the dip of the faults changes direction either along the strike or dip. For example, in the San Antonio vein along the drift north of the Cuatro Vientos shaft, the vein dips west at the top of the stopes, then becomes vertical, and dips east at the bottom of the stopes. In such an occurrence the terms "footwall" and "hanging wall" are not strictly applicable. In this particular example the west side of the breccia zone has a smooth wall, and thus is analogous to the footwall of most of the faults of the district.

\section{EXTENT}

A number of vein systems in the district have lengths measurable in hundreds of meters. The most important vein systems are the San Antonio, El Libertador, La Reina and Ampliación de La Reina, La Vida Nueva, and Amalia. Many other veins have been prospected but have yielded a relatively small amount of ore. The San Antonio vein system, consisting of at least three veins, has been explored continuously for a length of 550 meters, although the extent of mineralization is variable over this length. The El Libertador vein has been explored for a length of 450 meters.

The average thickness of the ore zone (consisting of about half wall rock) in the San Antonio mine is 2 meters, although in places it is as much as 3 or 4 meters. The thickest ore zone in the district is found on the La Reina claim, where there is a manganiferous brecciated zone as much as 8 meters thick. The majority of the other deposits have thicknesses of 1 to 2 meters or less.

None of the deposits has been explored to any great depth. The Cuatro Vientos shaft on the San Antonio vein is said to have reached a depth of 42 meters; it has been filled in to a depth of 33 meters. The main drift along the San Antonio vein is at the 23-meter level. For the most part ore was found in the floor, but there is very little evidence to show how much deeper it may extend. On the west vein of the La Vida Nueva claim a winze reached a depth of about 40 meters below the surface, but very little ore was found at this depth. Very few of the workings along the other veins in the district extend more than 20 to 30 meters below the surface.

\section{MINERALOGY OF ORE}

The manganese minerals consist entirely of manganese oxides, which occur in both massive and crystalline forms. X-ray studies by J. M. Axelrod and chemical studies by Michael Fleischer have resulted in the identification of true psilomelane, which is massive, sooty, and black; cryptomelane (much $\mathbf{K}$, some $\mathrm{Ba}$ ), which occurs as crystals; hollandite-cryptomelane (much $\mathbf{B a}$, little $\mathbf{K}$ ), occurring in botryoidal forms; coronadite, the lead-bearing member of the psilomelane group, 
identified from the Amalia No. 2 mine; and an unnamed mineral so far identified only by X-ray studies, which may be imperfectly crystallized psilomelane. The composition of these minerals, as given by Fleischer and Richmond, ${ }^{26}$ is listed in the following table.

Manganese oxide minerals from the Talamantes district

Psilomelane........... $\mathrm{BaR}_{9} \mathrm{O}_{18 .} 2 \mathrm{H}_{2} \mathrm{O}$ (?), $\mathrm{R}=\mathrm{Mn}^{\mathrm{IV}}$ chiefly, also $\mathrm{Mn}^{\mathrm{II}}$, Co.

Cryptomelane .......... $\mathrm{KR}_{8} \mathrm{O}_{16}$ (?), $\mathrm{R}=\mathrm{Mn}^{\mathrm{IV}}$ chiefly, also $\mathrm{Mn}{ }^{\mathrm{II}}, \mathrm{Zn}$, Co.

Hollandite ........... $\mathrm{BaR}_{8} \mathrm{O}_{16}(?), \mathrm{R}=\mathrm{Mn}^{\mathrm{IV}}$ chiefly, also $\mathrm{Fe}{ }^{\mathrm{III}}, \mathrm{Mn}^{\mathrm{II}}$, Co.

Coronadite . . ........ $\mathrm{PbR}_{8} \mathrm{O}_{18}\left(\right.$ ?), $\mathrm{R}=\mathrm{Mn}^{\mathrm{IV}}$ chiefly, also $\mathrm{Mn}^{\mathbf{I I}}, \mathrm{Cu}, \mathrm{Zn}$.

The manganese oxides are accompanied in many places by later veinlets of white calcite and chalcedony. (See pl. $36 \mathrm{~B}$.) In places the calcite occurs in thick crystalline masses lining vugs and cavities. Some of the calcite shows a yellow-green fluorescence similar to that of hyalite. Gypsum and quartz accompany the calcite in places. Iron oxides, chiefly hematite, are present locally in the ore zones.

Barite is a common constituent of the ore, and thick barite veins containing minor amounts of manganese oxide occur in the district. Where barite and manganese oxide occur together, the barite appears to have formed earlier. Some of the barite is coarsely crystalline. The barite veins are accompanied by crystalline quartz, including amethyst. The barite veins are especially prominent on the El Pavo Real claim, the Belém claim, and in the vein system following the La Concepción fault on the east side of the Mesa de Talamantes. On the Belém claim and extending to the north the barite veins attain thicknesses of 8 meters and may be traced continuously for several hundred meters. At the south end of this vein system galena occurs in small quantities, and the veins are said to contain gold and silver. Only a small production of manganese ore has been obtained from the barite veins, although they have been prospected in a number of places. The manganese ore in the barite veins contains a high percentage of silica because of the abundance of quartz.

\section{GRADE OF ORE}

The manganese content in the more important veins of the district is between 20 and 30 percent, although the thinner veins that are free from wall rock contain 40 to 45 percent of manganese. The rhyolite fragments that make up about half the ore are partly sorted out by hand jigging, increasing the grade of the shipping product to between 40 and 44 percent of manganese. Ore shipped from the San Antonio mine to the Metals Reserve Co. has averaged 42 to 43 percent of manganese and about 9 percent of silica.

\footnotetext{
${ }^{20}$ Fleischer, Michael, and Richmond, W. E., The manganese oxide minerals, a preliminary report : Ecou. Geology, vol. 38, pp. 269-286, 1943.
} 


\section{CHEMICAL COMPOSITION OF ORE}

Tungsten occurs in the manganese ore to the extent of one-half to $11 / 2$ percent of $\mathrm{WO}_{3}$. It is believed not to be of economic value because of its low percentage and the difficulty of its extraction. Fleischer states that "comparison of numerous analyses of manganese specimens from this district shows clearly that the tungsten is in a barium manganate, identified by X-ray study as psilomelane." In an unpublished report he has compiled a list of all the reported occurrences of tungsten in manganese oxide ores. Eight localities have been described in published reports, and 23 additional localities have been found during recent studies by the Geological Survey. In the localities in which the manganese oxide mineral containing the tungsten was definitely identified, it was found to be psilomelane in 21 localities out of a total of 28 . Fleischer states that it has not yet been proved whether the tungsten occurs as part of the crystal lattice of the mineral or whether it has been adsorbed on the surface, although the former seems more likely. The following complete analysis was made of a specimen of psilomelane (see pl. $37 \mathrm{~A}$ ) collected by Trask from the San Antonio mine. This specimen contained 2.92 percent of $\mathrm{WO}_{3}$.

Analysis of psilomelane, San Antonio mine, Talamantes district

[Analyzed by Michael Fleischer]

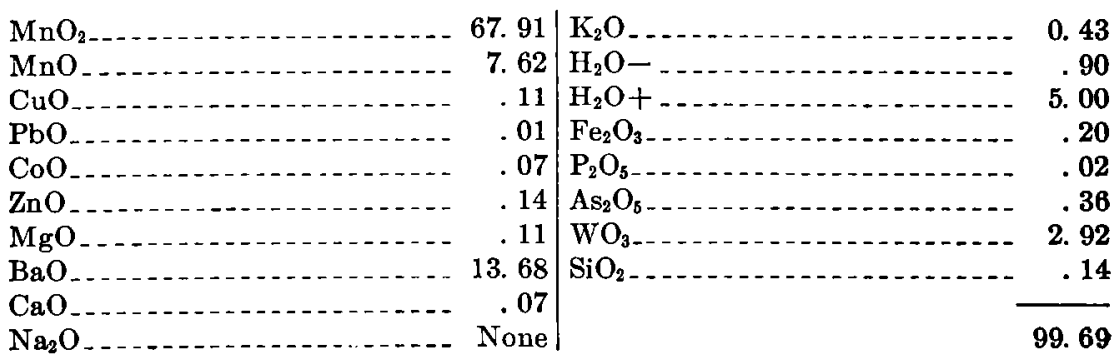

Specific gravity (pycnometer), 4.43 .

Active oxygen, 12.54 and 12.46 .

Total $\mathrm{MnO}, 62.82$ and 63.24 .

Barium is a prominent constituent of the ore. A large part of it. is in the mineral psilomelane and also in hollandite-cryptomelane, but part of it occurs in the mineral barite. The presence of thick barite veins in the district has already been pointed out.

Fleischer has calculated the ratios of $\mathrm{Mn}, \mathrm{BaO}$, and $\mathrm{WO}_{3}$ in various analyses made of the manganese ores. These ratios are presented on page 197.

Fleischer points out that the material from the San Antonio claim shows remarkable constancy in the ratios. There is an unusually high 
Ratios, in peroent by weight, of $\mathrm{Mn}, \mathrm{BaO}$, and $\mathrm{WO}_{\mathrm{a}}$ in manganese ores of Talamantes district

\begin{tabular}{|c|c|c|c|c|}
\hline Sample No. 1 & Name of claim & $\mathrm{BaO}: \mathrm{Mn}$ & $\mathrm{WO}_{3}: \mathrm{Mn}$ & $\mathrm{BaO}: \mathrm{WO}_{3}$ \\
\hline AS1 & San Antonio. & 0.26 & 0.040 & 6.4 \\
\hline AS2 & - _. - do do & .29 & .048 & 6. 1 \\
\hline AS3 & $\ldots$..... do_. & .28 & 037 & 7. 4 \\
\hline $\mathrm{D}-1885^{2}$ & . $\mathrm{do}_{-}$ & .28 & 060 & 4. $\overline{7}$ \\
\hline $119 \ldots \ldots$ & ..... do_. & .25 & .037 & 6.7 \\
\hline 226 & do_. & .22 & .034 & 6. 4 \\
\hline $227-$ & - do $_{2}$ & .26 & .040 & 6.4 \\
\hline 189 & El Libertador... & .32 & .036 & 8. 8 \\
\hline 190 & $\ldots \mathrm{do}_{-}$ & .19 & 018 & 10.4 \\
\hline 192 & $=-\mathrm{do}_{-}$ & .17 & .011 & 16. \\
\hline 198 & La Protección .... & .25 & .016 & 15. 6 \\
\hline 200 & El Pavo Real & .27 & .001 & 198 \\
\hline 205 & La India & 16 & .014 & 11. 3 \\
\hline 219 & LaVida Nueva_. & .22 & .016 & 14. 1 \\
\hline
\end{tabular}

Numbers are the same as those of analyses given in succeding tables.

2 Selected specimen of psilomelane for which complete analysis is given in the preceding table.

tungsten content in sample D-1885, which is a selected mineral specimen. He suggests that the deviations from these ratios shown by material from the other claims may be due to admixture of other manganese minerals. Sample 200 from the El Pavo Real claim, however, seems anomalous.

Aside from the manganese, barium, and tungsten, the main constituents of the ore are silica and iron. The silica content of the ore as it occurs in place is as much as 35 percent, because rhyolite fragments comprise about half the ore, but in the sorted ore the percentage is considerably less. In ore shipped to the Metals Reserve Company from the San Antonio mine the silica content has averaged about 9 percent. In this shipping ore the iron averages about $21 / 2$ percent, alumina 1 percent, zinc and copper each about 0.1 percent, and phosphorus 0.001 percent. The lead content is reported as "nil" in most shipments from the San Antonio mine, but in certain localities in the Talamantes district it occurs to the extent of several percent. On the Belém claim galena may be observed with the naked eye in specimens of the manganese ore. A small specimen of a manganese mineral collected from the Amalia No. 2 claim by W. J. Shedwick of the Metals Reserve Company was identified by X-ray study as a coronadite, with one-third of the lead replaced by barium. This specimen contained 1.75 percent $\mathrm{WO}_{3}, 19.30$ percent $\mathrm{PbO}$, and 6.21 percent $\mathrm{BaO}$. None of the samples of ore studied by the Geological Survey showed appreciable cobalt by qualitative tests.

An analysis of a composite grab sample collected by Trask from the dump at the San Antonio mine follows.

Composite samples of run-of-mine ore, sorted shipping ore, and 
rejected waste from the San Antonio mine collected by the writers were analyzed with the following results:

Analysis of manganese ore from dump, San Antonio mine

[Analyzed by J. R. Fyfe, Foreign Economic Administration]

\begin{tabular}{|c|c|c|}
\hline [n. & 26. 6 & $\mathrm{Cu}_{\ldots}$ \\
\hline $\mathrm{SiO}_{2-\ldots}$ & 36. 9 & $\mathrm{~Pb}_{\ldots} \ldots$ \\
\hline $\mathrm{Fe}_{\ldots}$ & 3. 8 & \\
\hline $\mathrm{WO}_{3 \ldots \ldots}$ & 1. 28 & $\mathbf{S}_{\ldots} \ldots$ \\
\hline $\mathrm{Al}_{2} \mathrm{O}_{3}$ & .15 & $\mathbf{T i}$ \\
\hline $\mathrm{Zn}$ & .15 & \\
\hline
\end{tabular}

Analyses of composite samples of manganese ore, San Antonio mine [Analyses by Michael Fleischer]

\begin{tabular}{|c|c|c|c|c|c|c|}
\hline $\begin{array}{c}\text { Sample } \\
\text { No. }\end{array}$ & Type of ore & Mn & $\mathrm{WO}_{3}$ & $\mathrm{~V}_{2} \mathrm{O}_{3}{ }^{1}$ & $\mathrm{BaO}^{2}$ & $\begin{array}{l}\text { Insol. } \\
\text { uble }\end{array}$ \\
\hline $\begin{array}{l}\text { AS1 } \\
\text { AS2 } \\
\text { AS3 }\end{array}$ & $\begin{array}{l}\text { Run-of-mine ore } \\
\text { Shipping ore, sorted.- } \\
\text { Waste dump }\end{array}$ & $\begin{array}{l}32.0 \\
41.2 \\
16.1\end{array}$ & $\begin{array}{r}1.29 \\
1.96 \\
.60\end{array}$ & $\begin{array}{l}0.13 \\
.11 \\
\left(^{3}\right)\end{array}$ & $\begin{array}{r}8.23 \\
12.03 \\
4.45\end{array}$ & $\begin{array}{r}34.6 \\
5.8 \\
63.6\end{array}$ \\
\hline
\end{tabular}

1 Colorimetric, by M. D. Foster.

$\mathrm{BaO}$ soluble in $\mathrm{HCl}$.

- Not determined.

Some 37 samples of ore from various parts of the Talamantes district, particularly from the dumps, were collected in 1943 by Parker D. Trask of the Geological Survey and Charles E. Pouliot of the Foreign Economic Administration. Analyses of these samples for manganese and tungsten and analyses of a few samples for barium also are given below.

Analyses of manganese ores, Talamantes district

\begin{tabular}{|c|c|c|c|c|c|}
\hline $\begin{array}{l}\text { Sample } \\
\text { No. } 1\end{array}$ & Name of claim & Locality and remarks & Mn & WO & $\mathrm{BaO}$ \\
\hline \multicolumn{6}{|c|}{ Samples of run-of-mine ore in place } \\
\hline 226 & San Antonio & \multirow{7}{*}{ 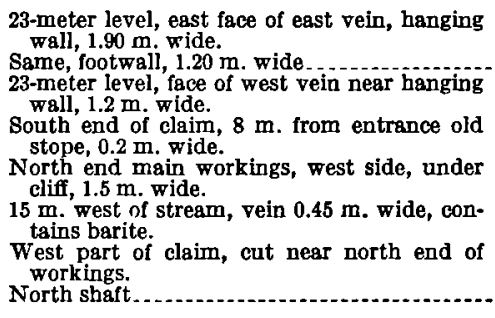 } & 44. 1 & 1. 62 & \multirow{2}{*}{$\begin{array}{r}9.7 \\
8.7 \\
\end{array}$} \\
\hline $\begin{array}{l}227 \\
229\end{array}$ & ... do do & & $\begin{array}{r}34.1 \\
17.85\end{array}$ & $\begin{array}{l}1.36 \\
0.58\end{array}$ & \\
\hline 215 & El Libertador. & & 41.64 & .05 & \\
\hline 203 & La Reina... & & 28.38 & .33 & \\
\hline 201 & El Pavo Real. & & 24.47 & 1.22 & \\
\hline 202 & ......do... & & 16.00 & 1.40 & \\
\hline 194 & Estels_.. & & 31.22 & 1.23 & \\
\hline \multicolumn{6}{|c|}{ Samples of sorted ore or concentrates } \\
\hline $\begin{array}{l}192 \\
223\end{array}$ & $\begin{array}{l}\text { El Libertador } \\
\text { El Libertador No. }\end{array}$ & \multirow{2}{*}{$\begin{array}{l}\text { Stock pile, south end of claim } \\
\text { Small pile of picked ore, Zaragosa vein } \\
\text { Jig concentrates......... }\end{array}$} & \multirow{2}{*}{$\begin{array}{r}50.1 \\
42.30 \\
47.4\end{array}$} & \multirow{2}{*}{$\begin{array}{r}0.53 \\
8.37 \\
.74\end{array}$} & \multirow{2}{*}{$\begin{array}{l}8.6 \\
10.4\end{array}$} \\
\hline 219 & La Vida Nueva........ & & & & \\
\hline
\end{tabular}

See footnotes at end of table. 
Analyses of manganese ores, Talamantes district-Continued

\begin{tabular}{|c|c|c|c|c|c|}
\hline $\begin{array}{l}\text { Sample } \\
\text { No. } 1\end{array}$ & Name of clsim & Locality and remarks & Mn & Wo, & $\mathrm{BaO}$; \\
\hline \multicolumn{6}{|c|}{ Samples from dumps } \\
\hline 119 & San Antonio. & Composite sample, dumps. . ................ & 26.7 & $\left\{\begin{array}{l}1.01 \\
0.98\end{array}\right.$ & 6.7 \\
\hline 196 & -.... do... & Tailings from shait east of Cuatro Vientos & 10.65 & .27 & \\
\hline 189 & El Libertador. & Dump at shaft at north end. & $\begin{array}{l}33.1 \\
35.6\end{array}$ & $\begin{array}{r}1.19 \\
.63\end{array}$ & 10. \\
\hline 191 & a.do... & Dump at shaft $85 \mathrm{~m}$. south of $190 \ldots$ & 31.68 & .72 & \\
\hline 193 & ..... do... & Dump at south end of long open cut & 19.95 & .37 & \\
\hline 216 & do & Waste dump, south end of claim & 21.20 & .27 & \\
\hline 217 & do... & Dump in creek west of main vein & 27. 40 & .31 & \\
\hline 222 & El Libertador No. 3 . & Hand-jig tailings, Zaragosa vein.. & 14.63 & .33 & \\
\hline 218 & La Vida Nueva...... & Jig tailings, main workings & 22.52 & .50 & \\
\hline $\begin{array}{l}220 \\
207\end{array}$ & La Vida Nueva No.2 & $\mathrm{Jig}$ tailings, west vein & 31.15 & .50 & \\
\hline 204 & La Reina & 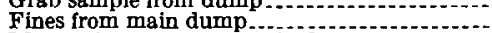 & 25. 20 & .40 & \\
\hline 206 & Ampliación de La & Manganiferous part of main dumps. & 22.64 & .50 & \\
\hline 221 & Amalia No. 2 & Waste dump, coarse ore... & 6. 28 & 0.27 & \\
\hline 224 & $\begin{array}{l}\text { Ampliación de La } \\
\text { Amalia No. } 2 .\end{array}$ & Small pile jig tailiags...-.- & 17.76 & .42 & \\
\hline $\begin{array}{l}198 \\
199\end{array}$ & $\begin{array}{l}\text { La Protección } \\
\text { El Pavo Real }\end{array}$ & $\begin{array}{l}\text { Dump, thought to be run-of-mine } \\
\text { Dump by small house, main eastward-trend- }\end{array}$ & $\begin{array}{l}\text { 37. } 5 \\
\text { 38. } 18\end{array}$ & $\begin{array}{r}.59 \\
1.27\end{array}$ & 9.2 \\
\hline 200 & .....do.. & $\begin{array}{l}\text { ing vein. } \\
\text { Dump from eastward-trending vein near edge } \\
\text { of cliff, } 150 \mathrm{~m} \text {. south of } 199 \text {. }\end{array}$ & 37.0 & .05 & 9.8 \\
\hline 205 & La India & Two main dumps & 32.6 & $\because 42$ & 5. 1 \\
\hline $\begin{array}{l}214 \\
225\end{array}$ & $\begin{array}{l}\text { La Esperanza. . } \\
\text { La Victoria.... }\end{array}$ & $\begin{array}{l}\text { Main dump near west line of clalm } \\
\text { Small pile jig trilings }\end{array}$ & $\begin{array}{l}26.22 \\
10.60\end{array}$ & $\begin{array}{r}.23 \\
1.00\end{array}$ & (3) \\
\hline
\end{tabular}

Samples of wall rock adjacent to ore zones

\begin{tabular}{|c|c|c|c|c|c|}
\hline 197 & San Antonio & Red rhyolite adjacent to ore zone at shaft east & 2.30 & 0.34 & \\
\hline 228 & $\mid \ldots . .$. do & Wall rock between east and west veins, 23 - & 4. 12 & .30 & \\
\hline 234 & El Libertador. & $\begin{array}{l}\text { meter level, } 3 \mathrm{~m} \text {. wide. } \\
\text { wall rock beside ore, at locality } 215 \text {, south end }\end{array}$ & 8.47 & .27 & \\
\hline 195 & Estela $\ldots . .$. & $\begin{array}{l}\text { of claim. } \\
\text { Wall rock adjacent to ore at north shaft, local- } \\
\text { ity } 194 .\end{array}$ & 1.16 & 1.32 & \\
\hline
\end{tabular}

1 Samples 119 to 206, inclusive, collected by Parker D. Trask; samples 207 to 234, inclusive, collected by Charles E. Pouliot. Samples 119, 189, 190, 192, 198, 200, 205, 219, 226, and 227 analyzed by Michael Fleischer of the Geological Survey; remaining samples analyzed by J. R. Fyfo of the Foreign Economic Administration.

BaO soluble in $\mathrm{HCl}$

Colorimetric determination, by F. S. Grimsldi; other determinations are gravimetric.

A summary of the range and average percentage of $\mathrm{Mn}$ and $\mathrm{WO}_{3}$ in run-of-mine ore and waste dumps is given below, as calculated from all available analyses.

Summary of analyses of manganese ore, Talamantes district

\begin{tabular}{|c|c|c|c|c|c|}
\hline & \multicolumn{2}{|c|}{ Mn } & \multicolumn{2}{|c|}{ wos } & \multirow{2}{*}{$\begin{array}{l}\text { Number of } \\
\text { analyses }\end{array}$} \\
\hline & Range & Average & Range & Average & \\
\hline $\begin{array}{l}\text { Run-of-mine ore } \\
\text { Waste dumps }\end{array}$ & 16. $0-44.1$ & $\begin{array}{l}29.9 \\
24.5\end{array}$ & $\begin{array}{r}0.05-1.52 \\
.05-1.27\end{array}$ & $\begin{array}{r}1.00 \\
.55\end{array}$ & $\begin{array}{r}9 \\
23\end{array}$ \\
\hline
\end{tabular}




\section{ORIGIN}

Adequate evidence was not found to establish clearly the origin of the deposits. Concerning certain features, however, there can be little doubt. The manganese minerals were deposited along brecciated fault zones by manganiferous solutions containing barium and tungsten. The minerals were deposited in open spaces in the breccia zones, and they probably also replaced the matrix of the breccia, but there, was little or no replacement of the rhyolite fragments of the breccia or the rhyolite of the wall rock. Along fissures that were not accompanied by breccia zones the manganese minerals were deposited as definite veinlets filling open cracks.

Two fundamental questions in connection with the origin cannot as yet be definitely answered: Were the deposits formed by ascending or by descending solutions, and were the manganese oxides the original manganese minerals that were deposited? In order to solve the first problem, further evidence is needed regarding behavior of the deposits at greater depths. At present insufficient exploration at depth (below 20 or 30 meters) has been done to throw much light on the subject. Certain features of the mineralogy and chemical composition of the ores, in particular the presence of tungsten in amounts of one-half to $11 / 2$ percent $\mathrm{WO}_{3}$ (as much as 2.9 percent $\mathrm{WO}_{3}$ in the pure psilomelane), seem suggestive of ascending hydrothermal solutions. Fleischer, however, who has gathered information on all known occurrences of tungsten in manganese ores, states that information is still insufficient to prove whether tungsten should be considered indicative of hypogene or supergene origin. The thick barite veins that carry galena, and in places gold and silver, seem definitely of hydrothermal origin.

The manganese oxide minerals in the barite veins appear to have formed later than the barite, but conclusive evidence that they represent a late hydrothermal stage or that they are of supergene origin was not found. Whether or not the manganese oxides now present were the original minerals deposited cannot be settled at the present time. No manganese minerals other than oxides have so far been discovered in the deposits.

\section{RESERVES}

In the Talamantes district reserves of inferred ore containing 20 to 30 percent of manganese are estimated to aggregate 100,000 to 125 ,000 tons. Shipping ore containing 40 to 44 percent of manganese amounts to approximately half this figure. More than half of this estimate represents ore in the San Antonio mine. The accuracy of the figures, however, is highly uncertain because of lack of data concerning the depth to which the deposits extend. The estimate is based 


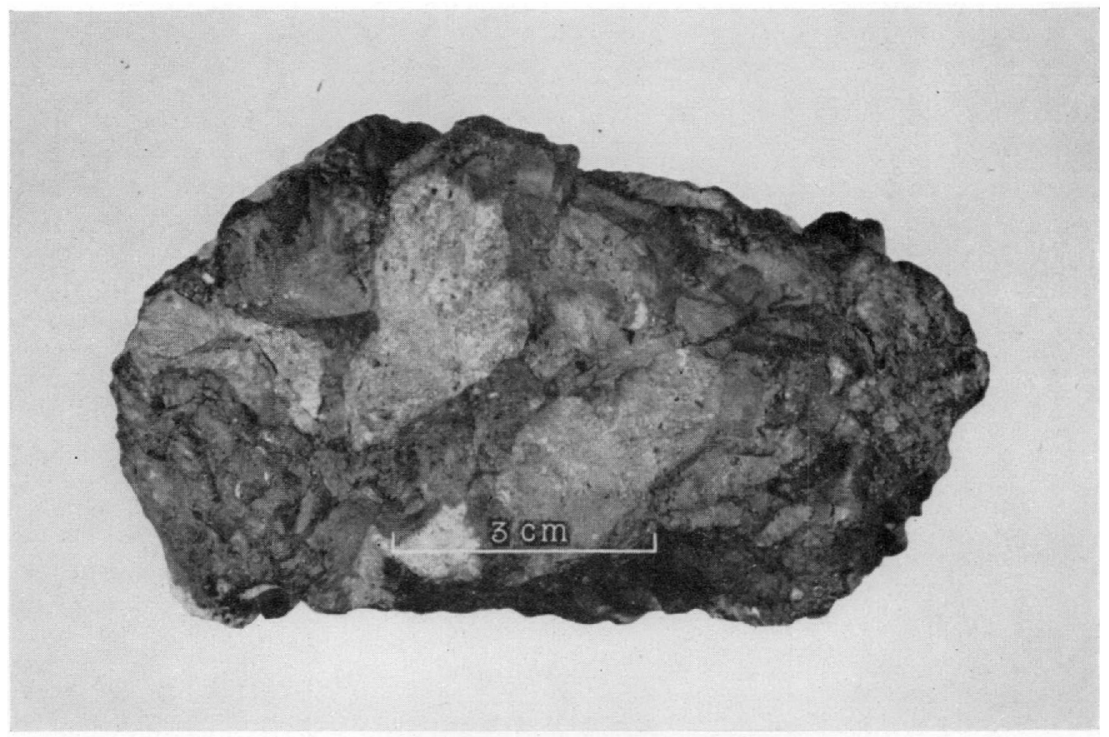

A. SPECIMEN OF TYPICAL ORE FROM SAN ANTONIO MINE.

Part of sample AS1, partial analysis of which is given on page 198. Light-colored fragments are rhyolite; darkcolored material is manganese oxide.

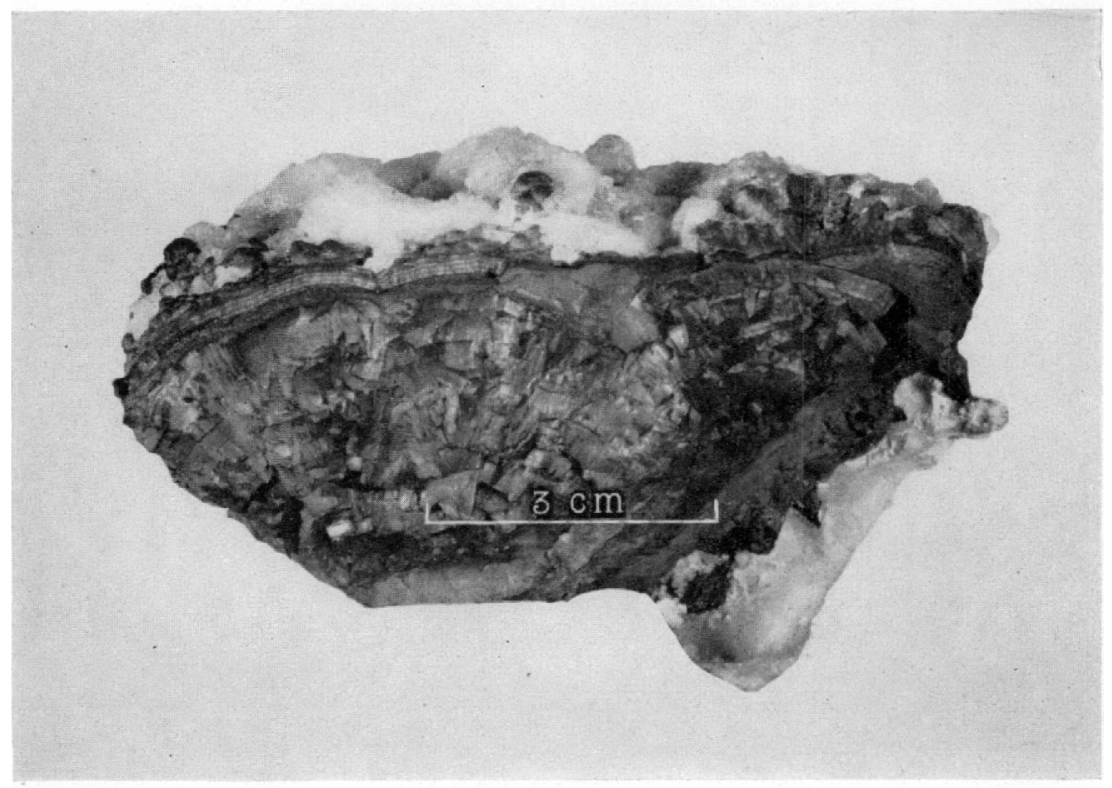

B. SPECIMEX OF OLE FROM FAX AXTOXIO MIXE. SIIUWING MANGANESE OXIDE ACCOMPANIED BY IATHR WHITE CACITE. 


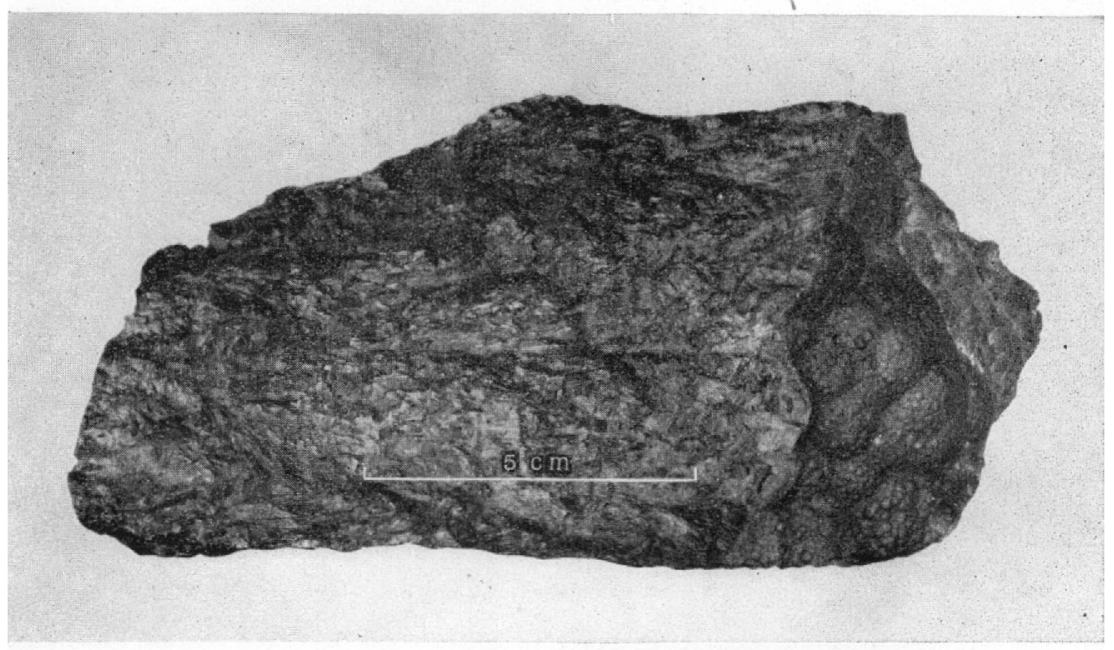

A. SPEGININ OF PSILOMLLANE FROM SAN ANTONIO MINE.

Complele andysis is given on page 196.

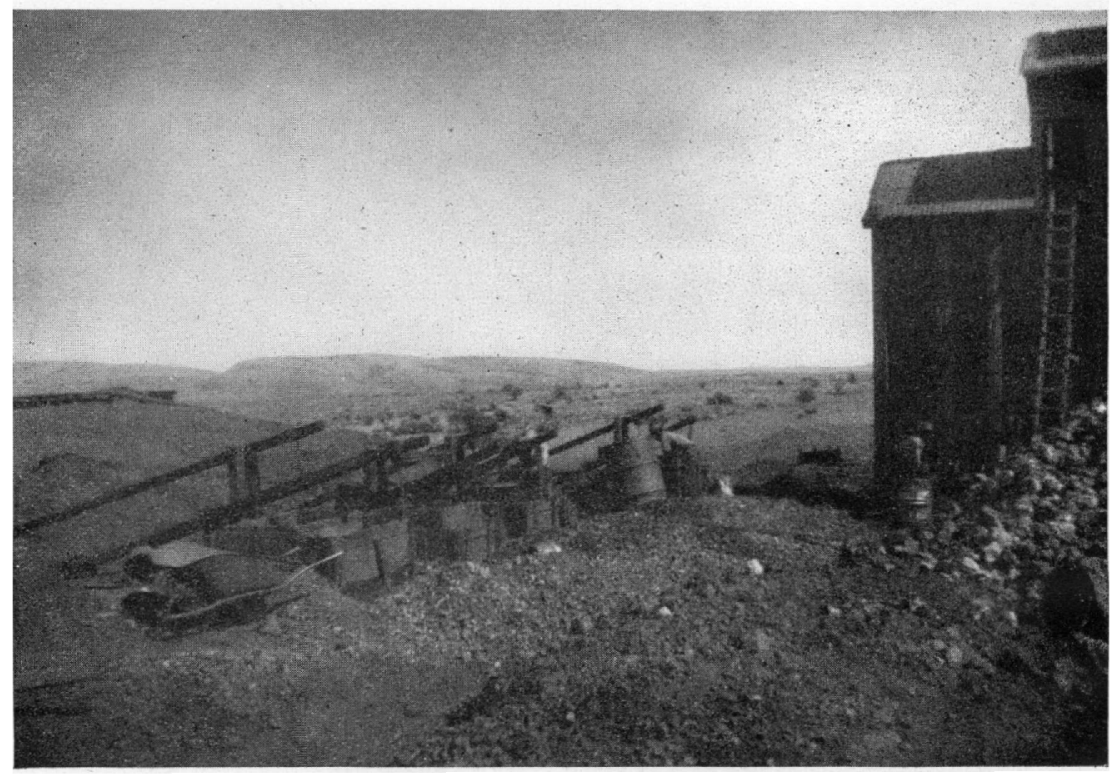

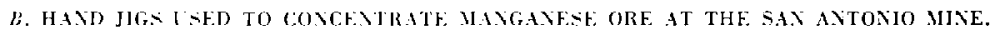


on an average depth of an additional 10 meters below the 23-meter level in the San Antonio mine. For additional depth something of the magnitude of 3,500 tons per meter of depth might be expected in that mine. If the various deposits in the district were found to extend to a much greater depth, for instance 50 to 100 meters, the figures given above for reserves would be considerably increased. Probably the maximum depth to be expected is about 120 meters below the top of the mesa, at which depth the limestone would probably be reached. It seems likely that conditions of mineralization in the limestone are different from those in the rhyolite, because of a difference in the physical character of the rock and its reaction to deformation. Breccia zones such as those forming the locale for the manganese deposits in the rhyolites were not observed in the limestone, nor have any manganese deposits been found in the limestone where it crops out east of the Mesa de Talamantes. Although 120 meters represents the probable maximum depth of mineralization, it does not follow that the manganese deposits extend to that depth.

In addition to the reserve figures given above, there is about 25,000 tons of dump material in the district containing 10 to 30 percent of manganese, which might be worked if a mill is constructed. The possibility exists that additional deposits may be found by further prospecting and exploration, inasmuch as some of the best deposits in the district, notably the San Antonio, were inconspicuous and unencouraging in outcrop.

The future production from the district will depend mainly upon the market for ore containing 40 to 44 percent of manganese. Should the need be great enough, a production of perhaps 5,000 tons of ore per year could probably be maintained for several years.

\section{METHODS OF MINING AND CONCENTRATION OF ORE}

The manganese deposits have been mined from the surface by means of open cuts or narrow trenches and underground by shallow shafts, drifts, and overhand stopes. The San Antonio mine has five shafts and an extensive 23-meter level from which ore has been stoped out to varying heights. Most of the other mines have no systematic levels. The San Antonio mine is equipped with two compressors and two hoists operated by gasoline engines. At the other mines there is practically no mechanical equipment, and all the mining operations are done by hand.

About half the ore as mined in the district consists of fragments of rhyolite surrounded by manganese oxide. An attempt is made to sort out the bulk of these rhyolite fragments by hand picking and by wet jigging. (See pl. 37 B.) No crushing is done at any of the mines. 
At the San Antonio mine the process of sorting is as follows: The ore is passed through a $3 / 4$-inch screen, and the oversize is hand-sorted; the undersize is then passed through a $1 / 8$-inch screen, and the oversize from this operation is worked by hand jigs and the undersize by a hydromotor jig. At the other mines in the district only hand jigs are used.

The methods of concentration used increase the manganese content of the ore from about 25 percent to about 40 percent, but they are inefficient and result in considerable loss. Dumps in the district contain 10 to 30 percent of manganese. Many of the dumps are reworked from time to time. There has been discussion of a project to construct a small plant along the Río de Valle Allende in order to concentrate the ore more efficiently, produce a higher-grade product, and work lowergrade ore than is possible by means of the hand-jigging operations. To test the feasibility of concentrating the ore by such a plant, a series of mill tests was made by T. E. Dickel of the Foreign Economic Administration, using samples collected from the San Antonio mine by W. J. Shedwick. The tests consisted of stage crushing through a Blake-type crusher, followed by stage reduction through a gyratory, the heads being concentrated in a Denver pulsating jig. The content of manganese was increased from 36.4 to 44.6 percent, and the percentage of extraction was 92.2 percent. The results of the tests are as follows:

Results of mill tests on manganese ore from San Antonio mine

\begin{tabular}{|c|c|c|c|c|}
\hline & $\begin{array}{c}\text { Weight in } \\
\text { grams }\end{array}$ & $\begin{array}{l}\text { Percent of } \\
\text { Mn }\end{array}$ & Units of $\mathrm{Mn}$ & $\begin{array}{c}\text { Percentage of } \\
\text { extraction }\end{array}$ \\
\hline $\begin{array}{l}\text { Heads, 10-mesh } \\
\text { Jig concentrates } \\
\text { Jig tailings } \\
\text { Sludge } \\
\text { Calculated heads. }\end{array}$ & $\begin{array}{r}814 \\
660 \\
150 \\
4 \\
814\end{array}$ & $\begin{array}{l}36.40 \\
44.64 \\
14.95 \\
29.59 \\
36.80\end{array}$ & $\begin{array}{r}0.29630 \\
.29462 \\
.02242 \\
.00183 \\
.31887\end{array}$ & $\begin{array}{r}92.34 \\
7.08 \\
.58 \\
100.00\end{array}$ \\
\hline
\end{tabular}

\section{DESCRIPTION OF THE MORE IMPORTANT MINES}

\section{SAN ANTONIO}

The San Antonio mine has had the largest production in the district and is estimated to contain the largest reserves. This mine is near the center of the Mesa de Talamantes. It has been developed by 5 shafts, a drift on the 23-meter level over a length of 550 meters, and short drifts at the 33-meter level. (See pl. 38.) The 23-meter level has a branch drift 150 meters long, now being extended toward the south. The main working shaft is the Cuatro Vientos, near the north end of the property, which is said to have attained a depth of 42 meters but has been filled in below the 33-meter level. 
The average strike of the main vein system is $\mathrm{N} .5^{\circ} \mathrm{W}$., and the dip is $60^{\circ}-80^{\circ} \mathrm{E}$. In the first 100 meters south of the Cuatro Vientos shaft both an eastward-dipping and a westward-dipping vein are present, and their intersection can be seen about 100 meters south of the shaft. A brecciated zone containing stringers of manganese oxide occurs in the block between the two veins. In this section of 100 meters the drift follows the westward-dipping vein, but south of this point only the eastward-dipping vein has been followed. North of the Cuatro Vientos shaft the vein is nearly vertical, and the dip changes from west at the top of the stopes to east at the bottom of the stopes. Another small vein, called the Veta Oriente, branches off to the southeast, starting from a point 205 meters south of the Cuatro Vientos shaft. In April 1944 this vein had been followed for 150 meters to the south, although in the last part of the drift the breccia zone was nearly barren of manganese oxide.

The San Antonio vein is not well marked on the surface and for the most part either does not crop out or is traced only by small stringer zones. The Veta Oriente can be traced on the surface by a stringer zone. Other stringer zones occur on the surface in the vicinity.

\section{EL LIBERTADOR}

The El Libertador mine is north of the Río de Valle Allende, near the eastern edge of the Mesa de Talamantes. It was worked for several years after 1930 but has been abandoned. The only work being done in April 1944 was by gambusinos, who were working some of the old dumps and exploring a possible extension of the vein at the north end of the mine. The El Libertador vein has been explored by open cuts, shallow shafts, and short drifts over a length of 450 meters. At the north end the strike is a few degrees east of north, but it swings around to slightly west of north at the south end. The dip is $75^{\circ}-80^{\circ} \mathrm{W}$. The vein contains a smooth footwall with striated surfaces. The striae are nearly horizontal; in one place the pitch was $15^{\circ} \mathrm{S}$. Above the smooth footwall is a breccia zone containing the manganese ore. Several cross fractures containing manganese oxides branch off from the main fracture toward the southeast. The vein has been stoped out from the surface to widths of 1 to 3 meters and to depths of 10 to 20 meters. Whether additional ore exists at greater depths is uncertain, because the floors of the stopes are for the most part caved.

\section{LA VIDA NUEVA}

The Vida Nueva mine is on the north bank of the Río de Valle Allende, west of the El Libertador. There are two main systems of drifts in addition to a number of smaller drifts and open cuts. Work 
at this mine in April 1944 occupied the largest number of men in the district outside of the San Antonio mine, although all the work was on a gambusino basis.

A western group of workings consists of an inclined shaft 25 meters deep, from which irregular drifts and stopes extend for a total distance of 120 meters. North of the shaft a winze has been sunk from the drift to a depth of 20 meters, or a total depth of about 40 meters below the surface, and short drifts have been driven from the bottom, but practically no ore was encountered at this depth. The manganese ore bodies in this mine are extremely irregular in outline and attitude, and the grade is variable.

On the eastern group of workings is an adit 225 meters long. Stoping has been done at intervals throughout this length, although in places the drift leaves the vein. At a point 90 meters from the surface a crosscut to the west encountered another vein, which was followed for about 40 meters and partly stoped out.

\section{LA REINA AND AMPLIACIÓN DE LA REINA}

The La Reina mine and the Ampliación de La Reina are located on the fault zone that forms the western border of the Mesa de Talamantes. Neither of these mines was being worked in April 1944. At the La Reina a thick manganiferous breccia zone as much as 8 meters wide has been mined from the surface by means of an open cut 100 meters long and 10 to 15 meters or more deep. Manganese oxide is scattered in veinlets and pockets through the breccia zone. Hematite occurs along the walls. The fault zone strikes N. $10^{\circ} \mathrm{W}$. and dips $80^{\circ}$ W. The bottom of the open cut is so caved that it cannot be determined whether the ore continues at depth. What is probably a continuation or branch of the same vein, across the canyon to the north in the Ampliación de La Reina, has been followed by drifts for a length of 200 meters and stoped out to varying heights. This vein has a thickness of $1 \frac{1}{2}$ to 2 meters. It strikes north and dips from $60^{\circ} \mathrm{W}$. to vertical.

\section{AMALIA}

The Amalia claims, on the south bank of the Río de Valle Allende, contain a series of parallel and intersecting veins, as indicated on plate 34. They have been followed in open cuts, short drifts, and stopes, in general not more than 10 to 15 meters deep. The veins are mostly vertical or dip $75^{\circ}-85^{\circ} \mathrm{E}$. or $\mathrm{W}$. The veins branch in many places. They range in thickness from less than 1 meter to as much as 3 meters. None of the individual veins have been followed for any great length. The ore in one of these veins contains the mineral coronadite, containing 19 percent of $\mathrm{PbO}$. This property was being worked in April 1944 but only on a small scale by gambusino operators. 
EL PAVo REAL

The El Pavo Real claim, south of the San Antonio mine, is of minor economic importance but of some geologic interest. The manganese deposits occur in volcanic breccia instead of in rhyolite, as in most of the mines of the district. Abundant barite veins are present, which contain crystals of amethyst in addition to manganese oxides. A number of veins of manganese oxide occur on the claim, but all are fairly short and narrow, and they have not been developed to any great depth. Ore has been extracted from open cuts. Gambusinos were working the deposit in April 1944.

\section{BELÉM}

The Belém claim is at the extreme south end of the Mesa de Talamantes. The boundaries of the claim are not shown on plate 34 , as no claim map was available to the writers. It was generally understood that title to the claim had been given up a number of years ago. The claim is noteworthy in that it contains very thick barite veins, some of them attaining a thickness of 8 meters. Manganese oxides are irregularly distributed through the barite. Some attempt was made to mine the manganese ore from open cuts, but it was found to be high in silica because of the large amount of quartz (partly amethyst) accompanying the barite. Furthermore, the veins contain several percent of lead in places. Galena was observed in some specimens. Some of the ore is said to contain gold and silver. The deposits had not been worked for a number of years prior to April 1944. 
METRIC EQUIVALENTS

LINEAR MEASURE

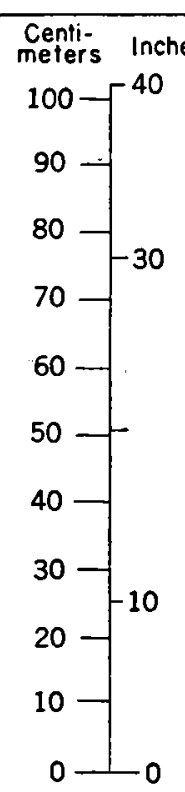

$1 \mathrm{~cm} .=0.3937 \mathrm{in}$ lin. $=2.5400 \mathrm{~cm}$

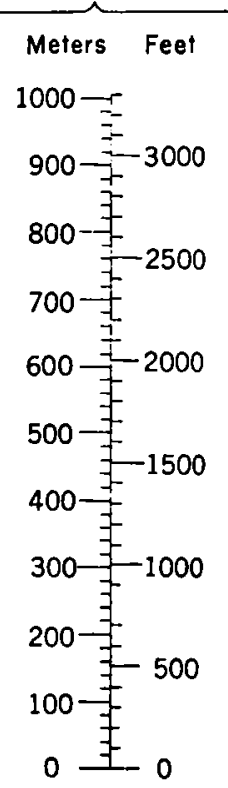

$1 \mathrm{~m}=3.2808 \mathrm{ft}$

$I_{\mathrm{ft}}=0.3048 \mathrm{~m} \quad \quad \mathrm{~km} .=0.6214$ mile I sq. $m .(m 2)=1.20$ sq. yd.

I hectare $(100 \times 100 \mathrm{~m})=2.47$ ocres

l cu. m. $(\mathrm{m} 3)=1.31 \mathrm{cu} . \mathrm{yd}$.

\section{WEIGHTS}

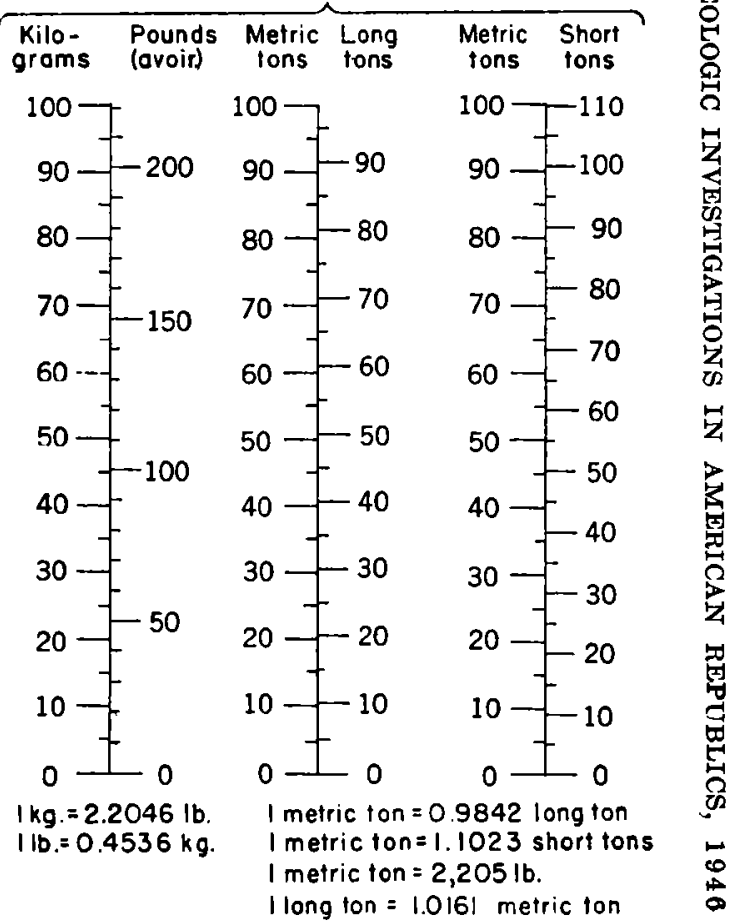




\section{INDEX}

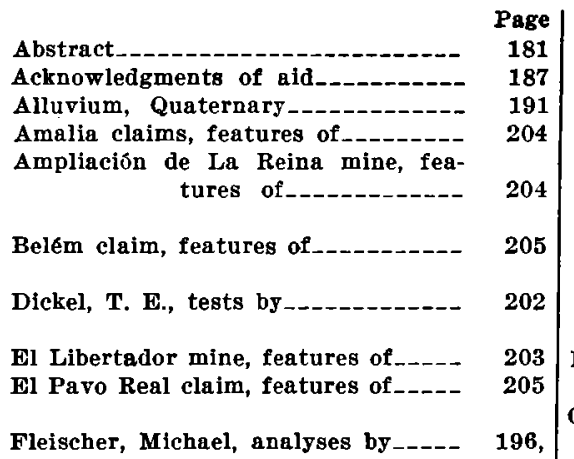
$197,198,199$

Fleischer, Michael, and Richmond,

W. E., analysis by

Fyfe, J. R., analyses by

Geographical features of district..._._ 183 ;

pl. 33

Geologic work

present_-_-_-_. 187

previous_-_._-

Geology_-_-_ 188-192 ; pls. 34, 35 A, 35 B stratigraphy alluvium, Quaternary_-_-_ 191 limestone, Cretaceous (?)

Talamantes volcanic series, $189 ; \mathrm{pl} .35 \mathrm{~A}$ Tertiary _-_ 189-191 rhyolite flows rhyolite tuff volcanic breceia, agglomerate, and tuffaceous sandstone - $_{190-191}$ structure__.__ 191-192; pls. 34, 35 B

History of operations 183-185

La Reina and Ampliación de La Reina mines, features of _-- 203-204

La Vida Nueva mine, features of _... 203-

204

Limestone, Cretaceous (?) --_-_--_ 188-

Location of district._._._-_._- 181-183

Metric equivalents, table showing _-_ 206

Mines, principal_-_-_-_-_-_-_-_- 202-205

Amalia claims, features of

Ampliación de La Reina mine, features of

Belem claim, features of _._._- 205

El Libertador mine, features of_ 203

El Pavo Real claim, features of_- 205
La Reina and Ampliacion de La Reina mines, features of - 204

La Vida Nueva mine, features of -

San Antonio mine, analyses of ore from_....... 196 , 198 ; pls. $36 \mathrm{~A}, 36 \mathrm{~B}, 37 \mathrm{~A}$ features of._._-_ 202-203; pl. 38 mill tests on ore from, table showing results of

Mining elaims_-_-_-_-_-_- 185-186; pl. 34

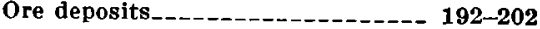

chemical composition of

manganese in San Antonio mine, composite samples, analyses of 198

manganese in San Antonio mine dump, analysis of

manganese ores in district, analyses of _-_._-_ 198-199 summary of analyses of _.

table showing ratios of $\mathrm{Mn}, \mathrm{BaO}$, and $\mathrm{WO}_{8}$ in psilomelane in San Antonio mine, analysis of

pl. 37 A

extent of

general features of _._-_-_-_ 192-193

grade of

methods of mining_-- 201-202; pl. $37 \mathrm{~B}$ mill tests on ore from San

Antonio mine, table showing results of mineralogy of _-_-_- 194-195; pl. $36 \mathrm{~B}$ manganese oxide minerals in district, table showing composition of _...... 195

mode of occurrence of _..._. 193 194 ; pl. 36 A origin of $200-201$

reserves of Ownership of claims_-_-_- 185-186; pl. 34

Production_-_-_ 183-185, 201-202; pl. 37 B from district, published figures for 1923,1925 , 1926.-

from Fernández properties, totals through 1944

from San Antonio mine, table showing results of mill tests on 
San Antonio mine, analyses of ore from 198 ; pl. 36 A, $36 \mathrm{~B}, 37 \mathrm{~A}$ features of mill tests on ore from, results of $\quad 202$ Smith, Robert L., thin-section study by, quoted 190

Stratigraphy alluvium, Quaternary__-_-_- 191 limestone, Cretaceous ( ?) _... 188$189 ;$ pl. 35 A Talamantes voleanic series, Tertiary 189-191
Page

rhyolite flows 189-190 rhyolite tuff_._-__-_-_ 190 voleanic breccia, agglomerate, and tuffaceous sandstone _._____ 190-191 Structure_-_-____ 191-192; pls. 34, $35 \mathrm{~B}$

Talamantes volcanic series_____-_ 189-191. rhyolite flows- 189-190 rhyolite tuff.-.- 190 volcanic breccia, agglomerate, and tuffaceous sandstone_--_-_----_-_- 190-191 


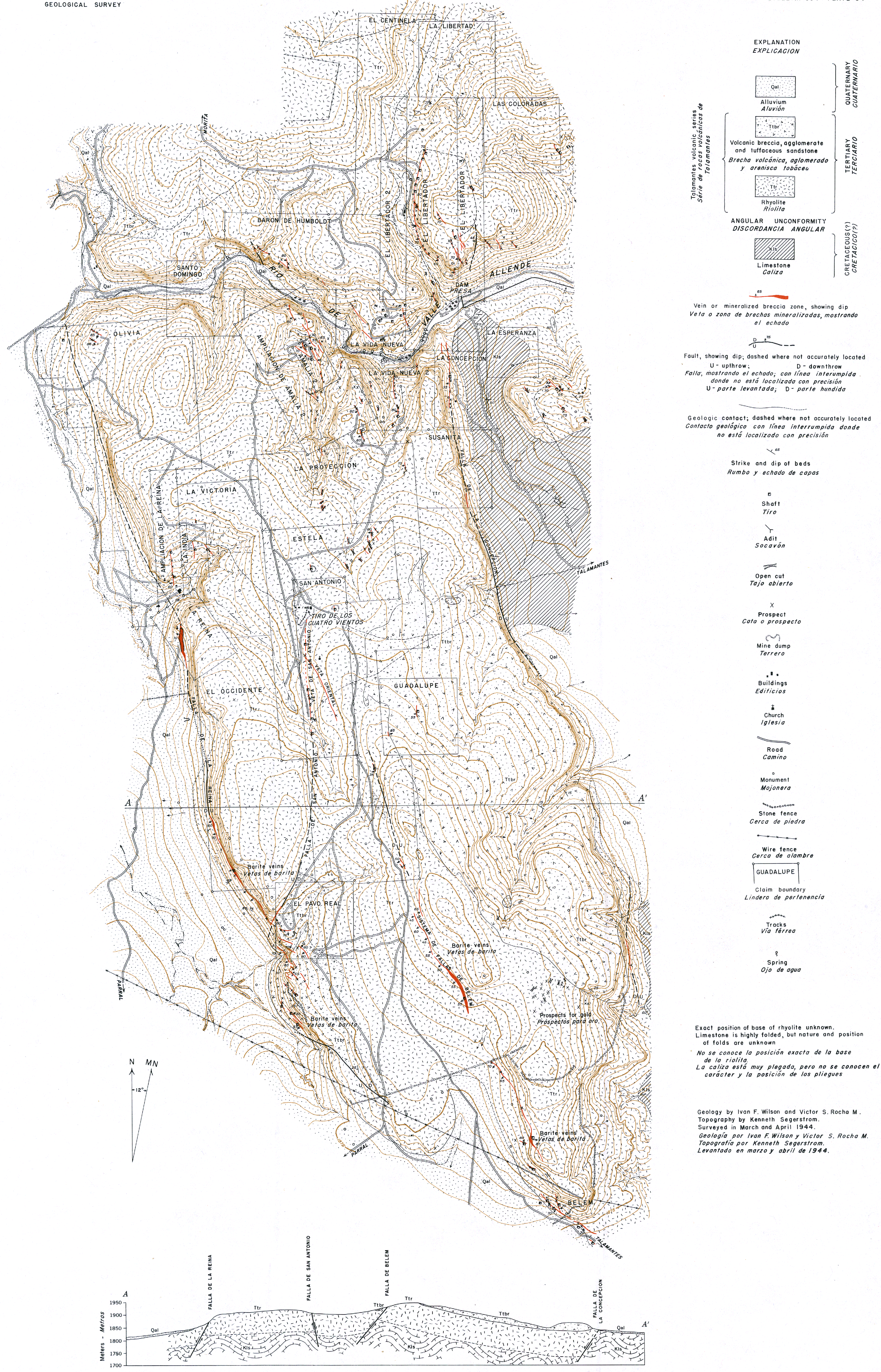

GEOLOGIC MAP AND STRUCTURE SECTION OF THE TALAMANTES MANGANESE DISTRICT, STATE OF CHIHUAHUA, MEXICO PLANO GEOLOGICO Y SECCION ESTRUGTURAL DE LA REGION MANGANESIFERA DE TALAMANTES, ESTADO DE CHIHUAHUA 

BULLETIN 954 - PLATE 38

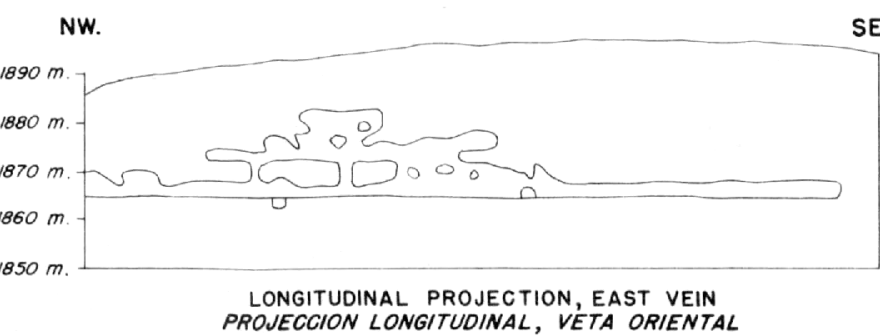

SE.

EXPLANATION

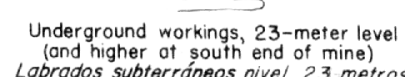

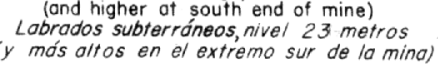

Underground workings, 33 -meter level
Labrodos subterroneos, nivel 33 metros

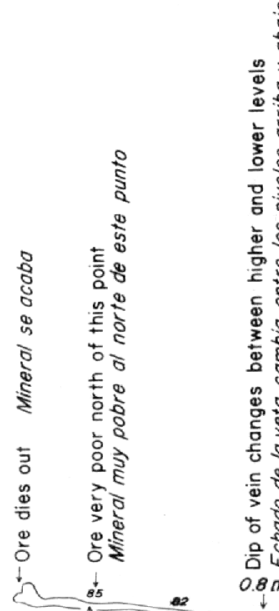

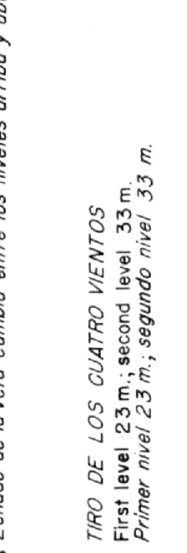

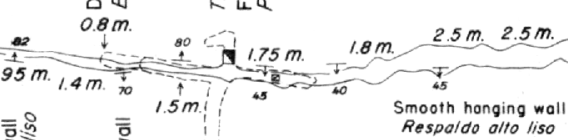

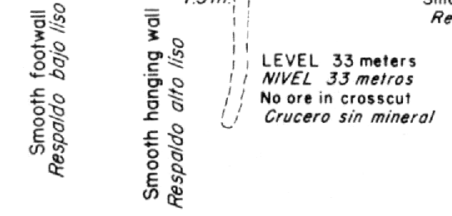

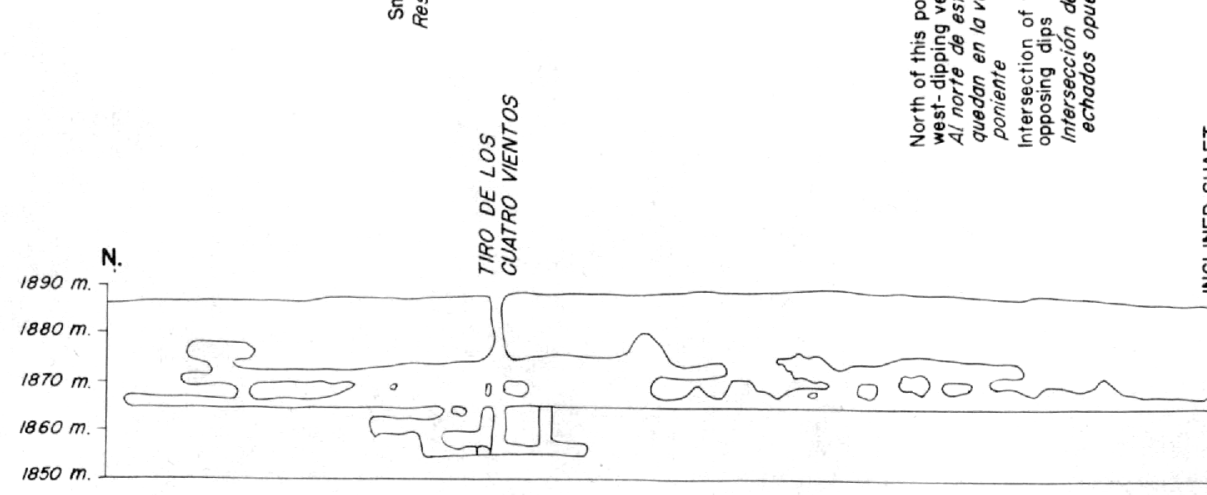

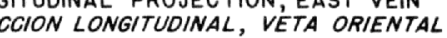

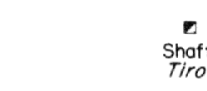

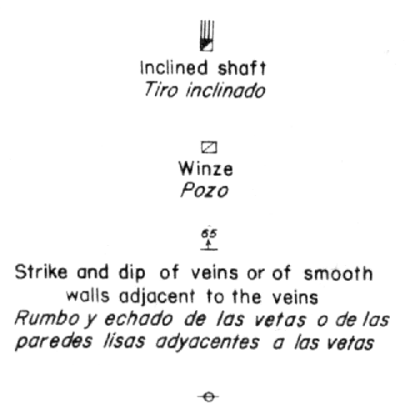

Strike of vertical veins
Rumbo de las vetas verticalos

$2.2 m$

Thickness of ore 20 ne in meters
Espesor de la zona de mineral, en metros

LONGITUDINAL SECTION, MAIN VEIN SYSTEM
SECCION LONGITUDINAL, SISTEMA PRINCIPAL DE LAS VETAS

MAP AND LONGITUDINAL SECTIONS OF THE SAN ANTONIO MANGANESE MINE, TALAMANTES DISTRICT, STATE OF GHIHUAHUA, MEXICO PLANO Y SECCIONES LONGITUDINALES DE LA MINA DE MANGANESO SAN ANTONIO, REGION DE TALAMANTES, ESTADO DE CHIHUAHUA 
$x^{2}=x^{2}$ 